\title{
A INSUSTENTÁVEL LEVEZA DO SER? A QUANTIFICAÇÃO DO DANO MORAL COLETIVO SOB A PERSPECTIVA DO FENÔMENO DA ILICITUDE LUCRATIVA E O CASO DIESELGATE $\mathrm{i}$
}

\author{
THE UNBEARABLE LIGHTNESS OF BEING? THE QUANTIFICATION OF COLLECTIVE MORAL \\ DAMAGES THROUGH THE PERSPECTIVE OF THE PHENOMENON OF LUCRATIVE ILLEGALITY \\ AND THE DIESELGATE
}

\author{
Pedro Rubim Borges Fortes ii \\ Pedro Farias Oliveira ${ }^{\text {ii }}$
}

\begin{abstract}
RESUMO: $O$ artigo examina como a ilicitude lucrativa é influenciada pela experiência da quantificação do dano moral coletivo. O estudo de caso do Dieselgate evidencia um cenário de subdissuasão no Brasil, decorrente da dependência do caminho (path dependence) que o judiciário herdou da antiga divisão entre os entendimentos dos tribunais superiores. A insustentável leveza das sanções econômicas aplicadas a empresas é um desafio a ser superado, o que pode ser feito mediante o abandono da quantificação dos danos morais coletivos pelo método do arbitramento de
\end{abstract}

\begin{abstract}
This article examines how the lucrative illegality is influenced by the experience of quantification of collective moral damage. The case study of Dieselgate reveals a setting of underdeterrence in Brazil, due to the path dependence in the judicial system resulting from the division of contrasting precedents of the higher courts. The unbearable lightness of economic sanctions applied to companies is a challenge to be overcome, which can be done by abandoning the quantification of collective moral damages by arbitration of minimum amount. The adoption of fairer criteria and methods,
\end{abstract}

\footnotetext{
' O presente artigo consiste em uma reflexão acadêmica em que a questão-problema, a metodologia de estudo de caso e a reflexão foram informados pela atuação profissional em 2017 e 2018 junto à 5a Promotoria de Justiça de Tutela Coletiva de Defesa do Consumidor, inclusive com manifestações na condição de fiscal da lei (custos legis) nos autos do processo judicial n.ำ 0412318-20.2015.8.19.0001 junto ao Juízo de Direito da $1^{\underline{a}}$ Vara Empresarial da Comarca da Capital do Estado do Rio de Janeiro. Por outro lado, os estudos do fenômeno da ilicitude lucrativa e da quantificação do dano moral coletivo constituem uma agenda de pesquisa acadêmica sobre a responsabilidade civil coletiva independente do caso concreto e o artigo deve ser recebido dentro desse contexto, eis que se trata de uma reflexão eminentemente acadêmica ao invés da defesa de uma posição doutrinária ou da posição de uma parte em um processo. Os autores são gratos aos professores Nelson Rosenvald, Guilherme Martins e Karina Fritz pela interlocução qualificada no debate sobre as funções da responsabilidade civil, pela discussão do estudo de caso concreto e pelo cuidado editorial da Revista do IBERC. Agradecemos ainda aos excelentes revisores anônimos cujos comentários, sugestões e feedback qualificado contribuíram para a melhoria da versão final do presente artigo.

ii Professor Visitante do PPGD da Faculdade de Direito da Universidade Federal do Rio de Janeiro (UFRJ) e Promotor de Justiça no Ministério Público do Estado do Rio de Janeiro (MPRJ). DPhil pela Universidade de Oxford, JSM pela Universidade de Stanford, LLM pela Universidade de Harvard, MBE pela COPPE/UFRJ, Bacharel em Administração pela PUC-Rio e Bacharel em Direito pela UFRJ. E-mail: pfortes@alumni.stanford.edu iii Professor Substituto de Direito Internacional Público da Universidade Federal do Rio de Janeiro (UFRJ) e Assessor Jurídico no Ministério Público do Estado do Rio de Janeiro. Mestre e Bacharel em Direito pela Universidade do Estado do Rio de Janeiro (UERJ). E-mail: pedroforj@yahoo.com.br
} 
valor mínimo. A adoção de critérios e métodos mais justos, que realmente levem em consideração as nuances do caso concreto, é o único meio de prestigiar as múltiplas funções da responsabilidade civil em uma medida adequada. Assim, é a virada matemática do Direito que pode trazer equilíbrio ao regime de incentivos do sistema de responsabilidade coletiva, coibindo a ilicitude lucrativa por intermédio dos efeitos irradiadores que advêm das cortes nacionais.

Palavras-chave: Dano Moral Coletivo. Ilicitude Lucrativa. Dieselgate. Quantificação. Virada Matemática do Direito. which would actually take into account the nuances of each concrete case, is the only means to duly regard the functions of civil liability to an adequate extent. Thus, it is the mathematical turn in law that can bring balance to the incentives system in collective responsibility, curbing lucrative illegality through the irradiating effects that resonate from national courts.

Keywords: Collective Moral Damages. Lucrative Illegality. Dieselgate. Quantification. Mathematical Turn in Law.

SUMÁRIO: 1. Introdução. 2. A perspectiva do fenômeno da ilicitude lucrativa. 2.1. O custo social e a internalização de externalidades. 3. Estudo de caso: o Dieselgate. 3.1. O desdobramento brasileiro. 3.2. A incorreta quantificação dos danos morais pelo uso do método do arbitramento de valor mínimo. 3.3. Os critérios doutrinários tradicionais. 3.4. O método da estimativa feita a partir do montante global da indenização por danos materiais. 3.5. O método bifásico. 4. O desafio da superação da "Insustentável Leveza do Ser". 4.1. Dependência do caminho e a necessidade da devida mudança. 4.2. A "Virada Matemática" do Direito: a necessidade da devida quantificação. 4.3. Os efeitos irradiadores das cortes: a necessidade de influenciar comportamentos. 5. Conclusão. Referências.

\section{INTRODUÇÃO}

No famoso romance de Milan Kundera, "A Insustentável Leveza do Ser",' a personagem Sabina cultiva uma existência destituída de quaisquer padrões em termos de suas relações afetivas, culturais e sociais. A aparente leveza de seu comportamento livremente descompromissado é, a rigor, insustentável diante do peso opressivo decorrente da vida desestruturada e solitária que decorre dessa liberdade absoluta. "A Insustentável Leveza do Ser" funciona como um relevante ponto de partida metafórico para uma reflexão sobre a tendência do direito brasileiro em não sancionar economicamente as empresas por suas transgressões coletivas. A leveza de ser da consequência jurídica do ilícito esvazia o peso da norma jurídica. Tal característica, entendida como a ausência de peso da sanção econômica, é insustentável por decorrer de uma liberdade descompromissada, e induz uma falta de engajamento e de comprometimento com o regime de responsabilidade civil. A hipótese do artigo é, portanto, que a leveza das consequências jurídicas leva ao descompromisso com as regras e, em última instância, a uma série de violações graves ao regime de responsabilidade civil.

O presente artigo apresenta, assim, a seguinte questão-problema: como a ilicitude lucrativa é influenciada pela experiência da quantificação do dano moral coletivo? A metodologia consiste no estudo de caso do Dieselgate, com foco específico na quantificação do valor dos danos morais coletivos. Esse estudo de caso possibilita uma reflexão sobre a calibragem adequada do regime de incentivos econômicos para o funcionamento do sistema de responsabilidade civil e a prevenção de

${ }^{1}$ Cf. KUNDERA, Milan. The Unbearable Lightness of Being. Nova York: Harper \& Row, 1984. 
transgressões coletivas. A análise é especialmente relevante para a literatura brasileira, na medida em que uma série de transgressões coletivas não recebeu o devido tratamento jurídico em termos de sanção econômica. Se o ilícito compensar economicamente, a sociedade brasileira tornará a ser vítima de novos e graves danos difusos e coletivos. Além disso, o ensaio do presente artigo é original, na medida em que supre uma lacuna na literatura brasileira de responsabilidade civil, ao examinar o caso do Dieselgate como ponto de partida empírico para uma análise da relação entre a quantificação do dano moral coletivo e o fenômeno da ilicitude lucrativa.

O artigo está organizado da seguinte maneira. Além desta introdução, a primeira parte explica em que consiste a ilicitude lucrativa, especialmente no contexto da responsabilidade coletiva. A segunda parte apresenta o estudo de caso do Dieselgate, explicando a fraude global, o processo judicial brasileiro, o uso inadequado do arbitramento do dano moral coletivo pelo valor mínimo, e também indicando como a estimativa deveria ter sido feita a partir do montante global das indenizações pelos danos materiais. A terceira parte traz as discussões teóricas sobre a questãoproblema, apresentando a dependência do caminho relativo ao histórico de precedentes jurisprudenciais como explicação para o reduzido valor das condenações no Brasil. Além disso, a "virada matemática" do direito e sua recomendação para a adoção de fórmulas numéricas para o cálculo adequado da justiça de certas decisões será discutida como possível inspiração para uma mudança de rumo. Ademais, será perquirida a influência dos efeitos irradiadores das cortes diante do estudo de caso do Dieselgate. Finalmente, serão externadas as conclusões finais.

\section{A PERSPECTIVA DO FENÔMENO DA ILICITUDE LUCRATIVA}

A ilicitude lucrativa pode ser descrita como o fenômeno que incentiva atores econômicos a descumprir a lei. Mais especificamente, refere-se neste artigo à conduta de empresas do mercado de consumo que violam sistematicamente o ordenamento jurídico, uma vez que suas transgressões não são sancionadas economicamente de forma eficiente. Em outras palavras, os fornecedores são recompensados pelas condutas praticadas em desacordo com as normas pátrias, pois o lucro auferido com a transgressão supera a eventual sanção a que se sujeitam. ${ }^{2}$

A premissa básica da economia clássica, que ainda permanece válida para a teoria geral econômica contemporânea, é a de que, a princípio, os indivíduos agem de acordo com incentivos, sejam eles positivos ou negativos. N. Gregory Mankiw elenca como um dos dez princípios básicos da economia o fato de que "pessoas respondem a incentivos". ${ }^{3}$ Nesse contexto, agentes econômicos racionais ${ }^{4}$ tendem a tomar decisões após comparar os custos e os benefícios delas decorrentes. ${ }^{5}$

\footnotetext{
2 Cf. FORTES, Pedro Rubim Borges. O fenômeno da ilicitude lucrativa. Revista Estudos Institucionais, Rio de Janeiro, v. 5, n. 1, p. 104-132, jan./abr. 2019.

${ }_{3}$ MANKIW, N. Gregory. Principles of microeconomics. 8. ed. Boston: Cengage Learning, 2016. p. 7.

4 Os mais recentes estudos econômicos, especialmente no campo da economia comportamental, esclarecem que nem sempre as pessoas agem na mais estrita acepção da racionalidade, e acabam tomando decisões que não maximizam seu bem-estar econômico. Veja, por todos, THALER, Richard, Misbehaving: The making of behavioural economics. Nova York: W. W. Norton \& Company, 2016; SUNSTEIN, Cass. Nudging: um guia (muito) resumido. Revista Estudos Institucionais, Rio de Janeiro, v. 3, n. 2, p. 1023-1034, jul./dez. 2017. Isso
} 
Assim, o Direito pode atuar como um incentivo ou desincentivo econômico. A tributação de determinado produto por meio de inovação legislativa é o mais clássico exemplo de desincentivo ao consumo. ${ }^{6}$ Nesse contexto, o regime de incentivos positivos (sanções econômicas premiais) e negativos (sanções econômicas punitivas) deve ser analisado como parte importante do modelo de responsabilidade civil, especialmente sob a perspectiva da análise econômica do direito e do processo dinâmico de tomada decisória típico da teoria dos jogos. Caso o regime jurídico seja mal calibrado economicamente, as consequências serão negativas em termos de comportamento humano e reação dos agentes racionais. Em um cenário de ausência de punições, o comportamento dos agentes econômicos tende a ser menos institucionalizado em termos de cumprimento e respeito às regras do jogo institucional. Por outro lado, se existirem sanções econômicas excessivas, os custos superiores serão internalizados como prejuízos para as empresas e transmitidos para acionistas ou consumidores, tornando-se um obstáculo ao progresso e desenvolvimento. Logo, o desafio sob a perspectiva da análise econômica do direito é o de que as sanções econômicas sejam calibradas sob medida, de maneira a evitar comportamentos prejudiciais à sociedade, mas sem que também criem desincentivos para os investimentos dos agentes econômicos no desenvolvimento da produção responsável de bens e serviços. ${ }^{7}$

Não é difícil chegar à conclusão de que, consignadas essas premissas, o próprio cumprimento (compliance) de normas jurídicas pelos atores sociais também é resultado de uma ponderação de custos e benefícios. ${ }^{8}$ Diante da possibilidade de não serem responsabilizadas ou de enfrentarem uma sanção branda, empresas certamente tentarão, por exemplo, se esquivar do pagamento de tributos ou do respeito a normas reguladoras de sua atividade econômica, da mesma forma que um homicida se sentiria mais tentado a matar alguém, não fosse o sistema persecutório e as elevadas penas previstas para esse tipo de crime. Tal ideia deveria ser incorporada a qualquer sistema de responsabilidade civil desde que Oliver Wendell Holmes Jr., em sua clássica palestra sobre os caminhos do direito, explicou que a noção de dever legal deve significar para o homem mau "uma profecia de que se ele fizer certas coisas, estará sujeito a consequências desagradáveis como o

ocorre porque os indivíduos se deparam com dilemas morais ou déficits informacionais. Assim, a ficção do homo economicus - aquele que tem por objetivo maximizar seus ganhos, abreviando esforços e custos - deve ser atualizada para um modelo que incorpore o comportamento humano também como parte da representação do processo decisório dentro das empresas, com a ressalva de que a racionalidade econômica estrita não mais se trata de um postulado que figura inconteste nos manuais de Economia.

5 A diminuição do preço de determinado produto, por exemplo, pode ser um incentivo para que pessoas comprem mais unidades dele, desde que haja algum benefício no consumo desses itens adicionais. Da mesma forma, o aumento na demanda pelo mesmo produto pode servir de incentivo para que os fornecedores produzam mais do mesmo bem, buscando atender à expansão do consumo e ao desejo de incrementar seus lucros. Os incentivos também podem ser negativos, isso é, podem induzir os atores econômicos a não praticar determinada ação, desde que façam com que os custos de tal conduta superem os benefícios por ela gerados.

6 É o que dá substrato fático para a extrafiscalidade de diversas espécies tributárias, como aquelas incidentes no comércio de cigarros. A tributação de tabaco não visa, primariamente, à arrecadação fiscal, mas sim ao desestímulo do consumo de tal produto, haja vista sua nocividade para o corpo humano.

7 Veja-se, a respeito, o clássico artigo de POLINSKY, M. A.; SHAVELL, Steven. Punitive damages: an economic analysis. Harvard Law Review, Cambridge, v. 111, p. 869-962, 1997.

8 Sobre a análise de custo e benefício através da visão da análise econômica do direito, confira-se POSNER, Richard A. Cost-benefit analysis: Definition, justification, and comment on conference papers. The Journal of Legal Studies, Chicago, v. 29, n. S2, p. 1153-1177, 2000. 
aprisionamento ou o pagamento obrigatório de dinheiro". ${ }^{9}$ Sem prejuízo da técnica jurídica e da perspectiva jurídico-doutrinária adequada, a visão do realismo jurídico também deve informar o sistema de responsabilidade, na medida em que os atores jurídicos - inclusive o tal homem mau tomam suas decisões a partir de uma análise de previsibilidade das consequências reais de seu comportamento a partir da experiência do direito na sociedade. ${ }^{10}$

No contexto brasileiro, aliás, a pesquisa empírica revelou que as empresas brasileiras não efetuam uma análise de risco consumerista, ou seja, do potencial impacto econômico negativo decorrente da lesão aos direitos coletivos dos consumidores pela introdução no mercado de um produto ou serviço em desacordo com as normas do Código de Defesa do Consumidor. ${ }^{11}$ As empresas brasileiras têm consciência de que não devem sofrer consequências econômicas por eventual transgressão coletiva e sequer realizam estudos prévios sobre os potenciais riscos de introduzir um contrato abusivo, um produto fraudulento ou um serviço precário. A leveza de ser da consequência jurídica ao ilícito esvazia o peso da norma jurídica e cria uma fenomenologia de repetição constante das transgressões.

$\mathrm{Na}$ hipótese abordada neste artigo, cria-se um cenário existencialmente problemático em que a leveza é insustentável. Ora, as empresas deveriam realizar estudos sobre os riscos econômicos decorrentes das transgressões coletivas e adotar as medidas necessárias e suficientes para a prevenção de danos coletivos, difusos e individuais homogêneos. Em regra geral, é apenas com a aplicação de uma sanção adequada pelo descumprimento da lei que os indivíduos são induzidos a cumpri-la, percebendo que o custo de oportunidade ${ }^{12}$ para auferir os ganhos da ilicitude supera o custo do simples cumprimento. As empresas, cujas decisões são tomadas por indivíduos racionais, não escapam dessa lógica, o que leva o renomado Professor Lawrence Friedman, da Stanford Law School a afirmar que "presumivelmente, é a análise de custo-benefício que guia o comportamento das empresas; se o benefício de cumprir a lei supera os custos, a empresa deve cumprir. Do contrário não". ${ }^{13}$ As empresas encaram a sanção pelo descumprimento do ordenamento como um custo de produção, mas como ele não é demasiadamente elevado, a escolha racional é simplesmente descumprir a lei, maximizando ganhos - ainda que decorrentes de uma atitude ilícita.

\subsection{O CUSTO SOCIAL E A INTERNALIZAÇÃO DE EXTERNALIDADES}

Para o estudo de caso que se fará neste artigo, é necessário compreender alguns conceitos indispensáveis para a análise econômica do Direito. Inicialmente, consigne-se que os custos de produção de uma empresa refletem, a princípio, a soma de seus custos explícitos e implícitos, sendo

\footnotetext{
${ }^{9}$ Cf. HOLMES, O. W. The Path of Law. Harvard Law Review, Cambridge, v. 110, p. 991-1009, 1997. Veja, ainda, TWINING, W. Bad Man Revisited. Cornell Law Review, Ithaca, v. 58, p. 275-303, 1972, p. 275-303.

${ }^{10}$ Sobre o realismo jurídico, veja LLEWELLYN, K. N. A Realistic Jurisprudence - The Next Step. Columbia Law Review, Nova York, v. 30, 1930, p. 431-465; e TWINING, W. Karl L/wewllyn and the Realist Movement. 2. ed. Cambridge: Cambridge University Press, 2012.

${ }_{11}$ Cf. FORTES, Pedro Rubim Borges. O fenômeno...

12 No vocábulo econômico, o custo de oportunidade traduz tudo aquilo que deve ser abdicado para que se adquira uma outra vantagem (MANKIW, N. Gregory. Principles..., p. 6).

${ }^{13}$ FRIEDMAN, Lawrence. Impact: how law affects behavior. Cambridge: Harvard University Press, 2016, p. 213.
} 
aqueles os que exigem um desembolso de dinheiro por parte do fornecedor, e estes os que não demandam qualquer aporte pecuniário. A contratação de trabalhadores e o pagamento de aluguéis são exemplos de custos explícitos, enquanto que os custos implícitos podem ser representados pela mera escolha de produzir determinado bem, em detrimento de outro. Nesse sentido, a alocação de quaisquer recursos, sejam materiais ou imateriais, é vista como uma escolha feita pela empresa, que compara o custo de oportunidade de determinada conduta com os ganhos dela decorrentes, buscando o maior resultado possível para a equação "lucro = receita total - custo total". ${ }^{14}$

Ocorre que as escolhas feitas por um ator econômico não raro afetam a sociedade como um todo, gerando o que os economistas denominam de externalidades. A rigor, as externalidades podem ser definidas como "o impacto das ações de uma pessoa sobre o bem-estar de outras que não participam daquelas ações". ${ }^{15}$ Sendo assim, uma externalidade pode ser positiva, quando tal impacto beneficia o terceiro afetado; ou negativa, quando a conduta traz repercussões adversas para o agente que não teve ingerência sobre a decisão tomada pelo outro ator. O exemplo mais clássico de externalidade negativa é a poluição gerada pela produção de determinado bem ou serviço. ${ }^{16} \mathrm{O}$ ar é poluído pelas usinas termoelétricas que produzem energia; os rios são poluídos por fertilizantes utilizados em fazendas que fornecem comida; a camada de ozônio é destruída por gases lançados de determinados aerossóis etc. Tudo isso gera um custo ambiental de difícil reparação, que não é computado pela empresa fornecedora em suas anotações contábeis, mas que é sofrido por toda a humanidade, durante gerações. A problemática se mostra ainda mais relevante quando se verifica que o Estado não possui, em regra, a completa informação para promover a reparação integral dos danos ambientais difusos, coletivos e individuais homogêneos. ${ }^{17}$

O que se observa quando uma empresa decide violar o Direito é, justamente, mais uma externalidade negativa. A partir de uma decisão racional em busca da maximização do lucro, que considera os riscos e a severidade de uma eventual sanção, o fornecedor transgride as normas jurídicas, produzindo impacto negativo em terceiros interessados no cumprimento do dispositivo violado. Tal norma ${ }^{18}$ pode ser uma lei em sentido amplo, uma sentença judicial ou até mesmo um contrato, de modo que a externalidade pode produzir efeitos em indivíduos determinados ou na

\footnotetext{
${ }^{14}$ MANKIW, N. Gregory. Principles..., p. 249.

15 MANKIW, N. Gregory. Principles..., p. 190.

16 Tal exemplo foi adotado pelo prêmio nobel de economia Ronald Coase no artigo seminal que deu origem ao famoso Teorema de Coase: COASE, Ronald $\mathrm{H}$. The problem of social cost. In: Classic papers in natural resource economics. Londres: Palgrave Macmillan, 1960, p. 87-137.

17 Como Richard Posner explica corretamente, o ponto anti-intervencionista do teorema de Coase não é que os mercados irão internalizar a poluição e outras externalidades negativas, já que vivemos em um mundo de custos de transação positivos: "o ponto é que a intervenção inteligente requer mais informação do que os governos costumam ter" POSNER, R. Ronald Coase and Methodology. Journal of Economic Perspectives, Pittsburgh, v. 7, n. 4, p. 195-210, 1993, p. 200.

$18 \mathrm{Em}$ que pese o tratamento interdisciplinar adotado nesse trabalho, a visão do regime de incentivos e do realismo jurídico, a tese defendida é plenamente compatível com a perspectiva do direito positivo, bem como a concepção kelseniana de norma jurídica, que abarca: (a) as normas genéricas, isso é, aquelas dotadas de generalidade e abstração e que obrigam, indiscriminadamente, a todos os que venham a se situar sob sua incidência; (b) as normas particulares, ou seja, aquelas que vinculam apenas pessoas determinadas, como é o caso dos negócios jurídicos e das leis de efeitos concretos; e (c) as individualizadas, que "pontualizam ou certificam, in concreto, as disposições anteriores, como se dá numa sentença judicial, ou numa provisão ou resolução administrativa" (REALE, Miguel. Lições preliminares de direito. 27. ed. São Paulo: Saraiva, 2007, p. 137. Grifos no original).
} 
sociedade como um todo, composta por terceiros que não participaram do processo decisório que culminou na adoção da conduta ilícita. O impacto de uma externalidade negativa, dessa forma, caracteriza um custo adicional de produção, a par dos já mencionados custos explícitos e implícitos. Trata-se de um custo externo, ou seja, aquele que não é suportado pelo produtor, mas por terceiros afetados pela decisão do fornecedor. ${ }^{19}$

Em uma análise holística, portanto, os custos totais de produção de determinado bem ou serviço são a soma dos custos privados explícitos e implícitos, assumidos pelo próprio fornecedor, com os custos externos, decorrentes de uma externalidade percebida pela sociedade como um todo. O resultado dessa análise é o que se entende por custo social de produção. ${ }^{20}$ É desejável que apenas sejam realizados atos em que a sociedade ganhe mais do que perca, devendo ser considerados os efeitos totais dos regimes jurídicos, inclusive os custos de mudança, os custos de transação e que a melhoria das condições para uns significa uma piora das condições para outros. ${ }^{21}$

Nesse contexto, a transgressão da lei, por si só, já representa uma externalidade negativa, por quebrar a confiança legítima e minar a eficácia e a credibilidade do ordenamento jurídico. ${ }^{22}$ No entanto, note-se que as normas jurídicas visam a tutelar os mais variados bens, além de legítimos interesses privados, de sorte que eventuais danos a esses bens jurídicos oportunizados pela transgressão normativa também constituem externalidades negativas integrantes do custo social. Essa é a hipótese do estudo de caso que será abordado neste artigo, no qual a empresa envolvida violou normas ambientais e consumeristas, colocando no mercado um produto inseguro e não condizente com sua publicidade, gerando danos à sociedade e aos consumidores.

Grande parte das vezes, o desafio da regulação do mercado nessas situações é internalizar as externalidades: elevar os custos internos do ator econômico a um patamar ótimo, que seja capaz de dissuadir o agente de tomar a decisão que produz nefastos impactos negativos. Logo, a internalização das externalidades nada mais é do que uma alteração do regime de incentivos incidente sobre determinada decisão racional, buscando fazer com que os atores sociais levem em conta os efeitos externos de suas ações. ${ }^{23}$

O legislador possui papel fundamental na definição desse regime de incentivos econômicos ${ }^{24}$ Contudo, diante da fluidez das relações sociais e produtivas, bem como das reiteradas violações de uma norma jurídica, com impactos negativos para os bens jurídicos por ela tutelados, a tarefa de internalizar as externalidades não cabe somente ao planejador social, mas também ao

${ }^{19}$ KRUGMAN, Paul; WELLS, Robin. Economics. 4. ed. Nova York: Worth Publishers, 2015, p. 466.

${ }_{20}$ Conforme a lição de Ronald Coase, devem ser levados em consideração especialmente os custos de transação, bem como os efeitos totais das políticas públicas e dos regimes sobre todas as esferas da vida (COASE, R. H. The problem..., p. 43).

${ }_{21}$ COASE, R. H. The problem..., p. 44

22 Sobre a importância da confiança, veja HARDIN, R. Trust and Trustworthiness. Nova York: Russell Sage Foundation, 2002. Sobre a visão de confiança como um "interesse encapsulado" e sobre uma visão dinâmica sobre os seus efeitos a partir do nível da realidade social, veja HARDIN, R. The street-level epistemology of trust. Politics \& Society, Pittsburgh, v. 21, n. 4, p. 505-529, 1993.

${ }^{23}$ KRUGMAN, Paul; WELLS, Robin. Economics..., p. 193.

${ }^{24}$ A internalização pode ser feita, por exemplo, por meio da instituição ou majoração de um tributo incidente sobre a prática geradora da externalidade negativa, como é o caso dos tributos extrafiscais aplicados à venda de cigarros, cuja externalidade é o dano à saúde que o produto proporciona. Também podem ser previstas punições para a conduta que se deseja inibir, como é a hipótese das sanções administrativas e penais por ofensa aos direitos do consumidor (art. 55 a $80, C D C$ ). 
Judiciário, que deve arbitrar condenações pecuniárias por atos ilícitos que efetivamente conduzam os transgressores a reavaliar suas decisões, considerando como custo interno as sanções estabelecidas pelo magistrado. ${ }^{25}$

Nesse sentido, as funções punitiva e precaucional da responsabilidade civil são absolutamente necessárias para a mudança dos incentivos, incrementando os custos inerentes às transgressões racionais na esteira da crescente consciência de que se tratam também de danos sociais de caráter difuso que transcendem a função de compensação individual e se caracterizam como uma medida de punição, retribuição e dissuasão para fins de compensação de danos sociais. ${ }^{26}$ A primeira função traduz a aplicação de uma sanção ao lesante, como maneira de desestimular novas condutas ilícitas, enquanto que a segunda possui o objetivo de inibir atividades potencialmente danosas. ${ }^{27} \mathrm{O}$ objetivo é amparar uma estratégia dissuasória (deterrence), que contemple a prevenção geral e específica de condutas danosas. ${ }^{28}$

Dito isso, é evidente que a incidência de tais facetas da responsabilidade civil não pode ser apenas uma ameaça, mas sim uma realidade efetiva. Caso contrário, as empresas não as levarão em consideração, com seriedade, para a análise da conduta a ser adotada. ${ }^{29}$ Nesse contexto, as condenações por transgressões devem aplicadas em um patamar ótimo, que realmente consiga influenciar a balança dos incentivos na direção do cumprimento da norma jurídica. ${ }^{30}$

\section{ESTUDO DE CASO: O DIESELGATE}

O Dieselgate foi um escândalo global que envolveu o grupo Volkswagen. Trata-se da maior fraude empresarial do século XXI, motivo pelo qual recebeu seu nome em referência ao escândalo de

${ }^{25}$ Existe uma vasta literatura sobre se juízes possuiriam as devidas capacidades institucionais ou se tal atividade caberia ao Poder Executivo e o Poder Judiciário deveria adotar uma posição de deferência. Veja, por exemplo, LEAL, Fernando e ARGUELHES, Diego Werneck, Dois Problemas de Operacionalização do Argumento de 'Capacidades Institucionais'. Revista Estudos Institucionais, Rio de Janeiro, v. 2, n. 1, p. 192-213, jan./jun. 2016; JORDÃO, Eduardo e RIBEIRO, Maurício Portugal, Como Desestruturar uma Agência Reguladora em Passos Simples, Revista Estudos Institucionais, Rio de Janeiro, v. 3, n. 1, p. 180-209, jan./jun. 2017; OLIVEIRA, Daniel Mitidieri Fernandes de, Algumas reflexões sobre o controle judicial da administração pública contemporânea, Revista Estudos Institucionais, Rio de Janeiro, v. 3, n. 1, p. 210-241, jan./jun. 2017; JORDÃO, Eduardo e CABRAL JÚNIOR, Renato Toledo, Teoria da Deferência e a Prática Judicial: Um Estudo Empírico sobre o Controle do TJRJ à AGENERSA, Revista Estudos Institucionais, Rio de Janeiro, v. 4, n. 1, p. 537-573, jul./dez. 2018. Um erro comum é deixar de avaliar a questão como sendo empírica e de adotar, por princípio, a premissa que um poder possuiria capacidade superior para a tomada de decisões complexas, aplicação de sanções e definição das regras do jogo. A postura de deferência deve ser adotada caso a caso, conforme a qualidade da decisão e o respeito que ela merece. Veja, a respeito, FORTES, Pedro. O impacto regulatório da tutela coletiva de direitos: a definição das regras e o desenvolvimento socioeconômico. In: JUNQUEIRA, Kátia (Org.). Repensando a regulação no Brasil: novas visões e propostas. Rio de Janeiro: Synergia, 2019.

${ }_{26}$ SHARKEY, Catherine M. Punitive damages as societal damages. Yale Law Journal, New Haven, v. 113, n. 2, p. 347-453, 2003, p. 347.

${ }_{27}$ ROSENVALD, Nelson. As funções da responsabilidade civil: a reparação e a pena civil. 2. ed. São Paulo: Atlas, 2014, p. 77.

${ }^{28} \mathrm{Em}$ obra mais recente, Nelson Rosenvald defende também a função restitutória da responsabilidade civil, ou seja, aquela que toma por base os ganhos auferidos pelo ofensor (gain based damages), os quais devem ser removidos, sem correspondência com a utilização do patrimônio do ofendido (disgorgement), ou devolvidos ao autor da demanda (restitutionary damages). (ROSENVALD, Nelson. A responsabilidade civil pelo ilícito lucrativo: o disgorgement e a indenização restitutória. Salvador: JusPodivm, 2019.)

${ }^{29}$ CRANSTON, Ross. Regulating business: law and consumer agencies. Springer, 1979.

${ }^{30}$ POLINSKY, M. A.; SHAVELL, Steven. Punitive damages..., p. 869. 
Watergate, evento este que, nos anos 1970, culminou na renúncia do presidente norte-americano Richard Nixon. A fraude global praticada pela fabricante alemã veio a público em 2015, principalmente com o anúncio de uma notificação feita ao grupo Volkswagen pela Agência de Proteção Ambiental dos Estados Unidos (Evironmental Protection Agency - EPA). ${ }^{31}$ Segundo a agência, a fabricante programou, de forma intencional, seus motores a diesel com tecnologia de injeção direta turbo (Turbocharged Direct Injection - TDI) para que os sistemas de controle de emissão de gases nocivos (NOx) somente fossem ativados durante condições específicas, presentes em testes em laboratório. ${ }^{32}$ Com isso, os automóveis equipados com os motores TDI, especialmente o modelo EA 189, apresentavam, em testes controlados, uma baixa emissão de partículas poluentes, porém mantinham, no uso cotidiano, o lançamento de perigosas substâncias na atmosfera acima do limite máximo permitido. ${ }^{33}$

Tal manobra era possibilitada por um software com funções de ruído e acústica, que permitia ao automóvel reconhecer quando estava sendo testado em um ambiente controlado, como um laboratório. ${ }^{34} \mathrm{O}$ artifício fraudulento - ou defeat device, no vocábulo em inglês - ativava um mecanismo no motor que reduzia as emissões de óxidos de nitrogênio sempre que um teste estivesse sendo realizado e depois o desligava, retornando o fluxo de gases nocivos ao patamar ilegal. ${ }^{35}$ Com isso, a Volkswagen preservava a vida útil do filtro de partículas, mantinha seu motor robusto e competitivo no exigente mercado moderno e, principalmente, externava a imagem de uma empresa "verde", preocupada com o meio ambiente e com a saúde da população em geral. ${ }^{36}$

Confrontados inicialmente pela agência ambiental do Estado da Califórnia (California Air Resources Board - CARB) em 2014, os executivos da Volkswagen inicialmente negaram a existência de qualquer dispositivo fraudulento em seus motores. ${ }^{37}$ Posteriormente, promoveram um recall dos modelos alegadamente afetados, o que não passou de mera tática diversionista, visto que os automóveis continuaram a apresentar níveis de emissões altíssimos. ${ }^{38}$ Após mais de um ano de procrastinação, período marcado pelo fornecimento, por parte da empresa, de informações falsas ou incompletas aos membros da entidade reguladora, a Volkswagen enfim veio a público em setembro de 2015 e admitiu a utilização do defeat device, bem como a ineficácia do recall realizado. ${ }^{39}$ Relatase, contudo, que a fabricante eliminou papeis e descartou e-mails, documentos que temiam que fossem usados como prova da conduta ilícita perpetrada. ${ }^{40}$

Em seguida, a Volkswagen, por intermédio de seu CEO, ofereceu suas desculpas à sociedade norte-americana ${ }^{41}$ e, inclusive, ao então presidente Barack Obama, em jantar

\footnotetext{
${ }^{31}$ EWING, J. Faster, higher, farther: the inside story of the Volkswagen scandal. Londres: Bantam Press, 2017, p. 211-212; SCHNEIDER, M. Volkswagen: Eine Deutsche Geschichte. Berlin: Berlin Verlag, 2016, p. 291-293.

32 MACDOUGALD, J. A. United States of America. In: RATTALMA, M. F. (Org.). The Dieselgate: a legal perspective. Cham: Springer, 2017, p. 83-84.

33 MACDOUGALD, J. A. United States..., p. 84.

${ }^{34}$ EWING, J. Faster, higher, farther..., p. 120-121.

${ }^{35}$ EWING, J. Faster, higher, farther..., p. 121-125.

${ }^{36}$ EWING, J. Faster, higher, farther..., p. 123-128; MACDOUGALD, J. A. United States..., p. 93-94.

${ }^{37}$ EWING, J. Faster, higher, farther..., p. 176-181.

38 EWING, J. Faster, higher, farther..., p. 182-185.

39 EWING, J. Faster, higher, farther..., p. 192-200.

${ }^{40}$ EWING, J. Faster, higher, farther..., p. 199-200.

${ }^{41}$ EWING, J. Faster, higher, farther..., p. 216.
} 
especialmente organizado pela chanceler alemã Angela Merkel em abril de $2016 .{ }^{42}$ No Judiciário estadunidense, o grupo concordou com um acordo que previu o pagamento de indenizações no valor global de 15 bilhões de dólares para os consumidores lesados, dentre os quais quatro bilhões e setecentos milhões de dólares se destinaram a fundos especiais de recomposição de bens coletivos. ${ }^{43}$

Ocorre que os carros equipados com o software fraudulento não foram comercializados apenas nos Estados Unidos, mas no mundo todo, o que motivou a iniciativa por ações de responsabilização em diversos Estados. ${ }^{44} \mathrm{Na}$ Itália, por exemplo, a Autoridade Italiana de Mercado e Competição identificou a prática ilícita também nos automóveis movidos a gasolina e constatou que os níveis de emissão de $\mathrm{CO}_{2}$ estavam sendo igualmente adulterados pelo artifício fraudulento. ${ }^{45} \mathrm{~A}$ Autoridade, então, aplicou a multa administrativa máxima à Volkswagen, no valor de 5 milhões de euros. ${ }^{46}$ Paralelamente, a Associação Civil Altroconsumo ajuizou ação coletiva em face da fabricante, a exemplo do que também ocorre no Canadá e nos Estados Unidos. ${ }^{47}$

\subsection{O DESDOBRAMENTO BRASILEIRO}

No Brasil, o Dieselgate deu origem à ação civil pública n.ำ 0412318-20.2015.8.19.0001, ajuizada pela Associação Brasileira de Defesa do Consumidor e Trabalhador, tendo o Ministério Público do Estado do Rio de Janeiro funcionado como fiscal da lei, nos termos do artigo $5^{\circ}$, $\S 1^{\circ}$, da Lei n. ${ }^{\circ} 7.347 / 1985.48$

A causa de pedir diz respeito à lesão provocada nos consumidores proprietários dos veículos Amarok diesel comercializados no Brasil, num total de 84.000 pessoas afetadas. A ação, em trâmite perante a 1르 Vara Empresarial da Comarca da Capital do Rio de Janeiro, foi sentenciada em 13 de setembro de 2017, oportunidade em que o magistrado competente condenou a Volkswagen nos seguintes termos:

Por tais fundamentos, JULGO PROCEDENTE O PEDIDO para:

1) condenar a ré a prestar informações claras, seguras e completas sobre todas as características dos veículos Amarok, de todos os anos de fabricação, comprovando, pormenorizadamente, através de documentação técnica hábil, quais os modelos que estão equipados com o - dispositivo manipulador e quais não estão, a fim de que sejam submetidos à perícia, não se prestando a tal fim superficiais informações e chamadas para "recall" sem maiores explicações, como as que foram recentemente

\footnotetext{
42 EWING, J. Faster, higher, farther..., p. 242.

43 EWING, J. Faster, higher, farther..., p. 235-238, 2017; MACDOUGALD, J. A. United States..., p. 96-99.

44 POSOCCO, L. France. In: RATTALMA, M. F. (Org.). The Dieselgate: a legal perspective. Cham: Springer, 2017, p. 24; SCHMID, C. U. Germany. In: RATTALMA, M. F. (Org.). The Dieselgate: a legal perspective. Cham: Springer, 2017, p. 44-45; TURNER, S. United Kingdom. In: RATTALMA, M. F. (Org.). The Dieselgate: a legal perspective. Cham: Springer, 2017, p. 75-82; KOLBA, P. Davids gegen Goliath: Der V-W Skandal und die Möglichkeit von Sammelklagen. Wien: Mandelbaum Verlag, 2017.

45 POSIO, G. Italy. In: RATTALMA, M. F. (Org.). The Dieselgate: a legal perspective. Cham: Springer, 2017, p. 47-50.

46 POSIO, G. Italy..., p. 51-53.

47 POSIO, G. Italy..., p. 59-62.

48 Art. 5․ (...) $\S 10$ O Ministério Público, se não intervier no processo como parte, atuará obrigatoriamente como fiscal da lei.
} 
divulgadas pela empresa, sob pena de multa diária de $\mathrm{R} \$, 50.000,00$ (cinquenta mil reais), a contar da sua intimação pessoal;

2) indenizar individualmente cada consumidor, proprietário da Amarok no Brasil, no valor de $\mathrm{R} \$ 54.000,00$ (cinquenta e quatro mil reais), por conta dos danos materiais causados pela instalação do software fraudulento nos referidos veículos, valor este acrescido de juros de mora de $1 \%$ a contar da citação e de correção monetária pelo IPCA a contar do ajuizamento dá ação;

3) indenizar individualmente cada consumidor, proprietário da Amarok no Brasil, no valor de $R \$ 10.000,00$ (dez mil reais), por conta dos danos morais causados pela instalação do software fraudulento nos referidos veículos valor este também acrescido de juros de mora de $1 \%$ a contar da citação e de correção monetária pelo IPCA a contar do ajuizamento da ação;

4) indenizar a sociedade brasileira a título de dano moral coletivo de caráter pedagógico e punitivo por conta da fraude coletiva causada no mercado de veículos automotores nacional em valor de $R \$ 1.000 .000,00$ (hum milhão de reais) a ser revertido ao Fundo Nacional de Defesa do Consumidor. ${ }^{49}$

A sentença restringiu a condenação aos modelos 2011 e 2012, que foram comprovadamente equipados com o famigerado motor EA 189 e software fraudulento que alterava a emissão de gases nocivos em ambientes controlados. O total de consumidores tocados pela sentença, portanto, foi de 17.057 , não tendo havido condenação da Volkswagen quanto às cerca de 67.000 unidades restantes por falta de provas.

Diante da condenação acima transcrita, o Ministério Público do Estado do Rio de Janeiro interpôs recurso de apelação, requerendo, dentre outras providências de caráter processual, a majoração do dano moral individual para $R \$ 100.000,00$ (cem mil reais) por consumidor lesado e o incremento do dano moral coletivo para $\mathrm{R} \$ 10.507 .112 .000,00$ (dez bilhões, quinhentos e sete milhões, cento e doze mil reais).

Em 07 de junho de 2019, foi publicado o acórdão proferido no julgamento conjunto das apelações do Parquet e da Volkswagen. A 9a Câmara Cível do Tribunal do Estado do Rio de Janeiro deu parcial provimento ao recurso da fabricante e negou provimento ao apelo do órgão ministerial, mantendo a condenação por danos morais - tanto individuais quanto coletivos - no mesmo valor fixado pelo juízo a quo. No mais, reformou a sentença em favor da ré, para que, no âmbito da condenação relativa aos danos materiais, fosse realizada liquidação com parâmetro definido pela avaliação mercadológica dos veículos Amarok 2012/2013.

A função pedagógico-punitiva da responsabilidade civil e a prevenção do fenômeno da ilicitude lucrativa recomendariam a fixação dos danos morais coletivos em patamar superior. ${ }^{50}$ É

49 Todas as citações e excertos de peças e atos processuais da ação civil pública n.․ 041231820.2015.8.19.0001 foram retirados de: BRASIL. Tribunal de Justiça do Estado do Rio de Janeiro. Apelação Cível n.ํ-0412318-20.2015.8.19.0001. Relator: Jds Des Ana Célia Montemor Soares. Disponível em: http://www4.tjri.jus.br/ejud/ConsultaProcesso.aspx?N=2018.001.39027. Acesso em: 26 nov. 2019.

50 Existe uma conceituada corrente acadêmica que defende uma visão monista da responsabilidade civil, não admitindo a sua função punitiva, mas apenas a sua função compensatória. Em relação aos danos morais coletivos, tal perspectiva foi defendida no Superior Tribunal de Justiça (STJ) pelo eminente e saudoso Ministro Teori Zavascki. Na academia, tem sido sustentada por Judith Martins Costa e por Mariana Pargendler. Veja ZAVASCKI, T. A. Processo coletivo: tutela de direitos coletivos e tutela coletiva de direitos. 4. ed. São Paulo: Revista dos Tribunais, 2009; MARTINS-COSTA, Judith Martins; PARGENDLER, Mariana. Usos e abusos da função punitiva (punitive damages e o direito brasileiro). Revista CEJ, Brasília, v. 9, n. 28, p. 15-32, 2005. Contudo, a discussão parece atualmente superada diante do reconhecimento dos danos morais coletivos pela jurisprudência pacífica dos nossos Tribunais Superiores e do entendimento doutrinário amplamente dominante, inclusive conforme consolidado no Enunciado 379 da IV Jornada de Direito Civil do CJF: "O art. 944, caput, do 
importante ressaltar, desde logo, que a questão transcende o estudo de caso concreto, na medida em que é recorrente na experiência brasileira o uso do método de quantificação do dano moral coletivo pelo arbitramento de valor mínimo. Assim, a prática judiciária brasileira tem se caracterizado pela aplicação de sanções pecuniárias de valor ínfimo e irrisório diante da gravidade da lesão, situação econômica do ofensor, benefício obtido e da reprovabilidade da conduta, configurando o fenômeno da ilicitude lucrativa. ${ }^{51}$ Ora, existem técnicas adequadas para a quantificação do dano moral coletivo que possibilitam o cálculo de um montante condizente com a sua função punitiva, precaucional e dissuasória. Assim, o Poder Judiciário deve aplicar sanções sob medida, de modo a estimular as empresas a adotar medidas de cautela e dever de cuidado para prevenir transgressões coletivas e evitar acidentes ambientais e de consumo. ${ }^{52}$ Logo, o presente estudo de caso possui uma força explanatória importante para a superação da crise existencial do sistema de responsabilidade civil brasileira e de sua insustentável leveza de ser, como será desenvolvido abaixo.

\subsection{A INCORRETA QUANTIFICAÇÃO DOS DANOS MORAIS PELO USO DO MÉTODO DO ARBITRAMENTO DE VALOR MÍNIMO}

A quantificação dos danos morais na ação civil pública n.․ 0412318-20.2015.8.19.0001, tanto no arbitramento inicial em primeira instância, quanto na revisão e reforma pelo órgão ad quem, seguiu o método de arbitramento de valor mínimo, que consiste na escolha de um valor "como o patamar mínimo de uma eventual condenação por danos morais coletivos". ${ }^{53} \mathrm{O}$ referido método é mais adequado para hipóteses em que a estimativa do valor do dano moral coletivo é complexa, isso é, quando não há "elementos de convicção ou parâmetros balizadores claros para o seu cálculo". 54

A imprecisão do arbitramento de valor mínimo não é desejável. A tendência atual é de gradual redução da utilização desse método, uma vez que há diversas ferramentas e técnicas mais efetivas para o cálculo da indenização extrapatrimonial por transgressões coletivas. No curso de uma ação corretamente instruída, são produzidas diversas provas que permitem a identificação das nuances que conformam os critérios quantificadores dos danos morais, sendo possível o recálculo do valor requerido para a prolação de sentença que satisfaça todas as facetas da responsabilidade civil.

Código Civil não afasta a possibilidade de se reconhecer a função punitiva ou pedagógica da responsabilidade civil".

51 Cf. FORTES, Pedro Rubim Borges. O fenômeno da ilicitude lucrativa...

52 Um revisor cego chamou a atenção para o fato de que a análise da calibragem das sanções pecuniárias depende não apenas da responsabilidade civil, mas também da responsabilidade administrativa, razão pela qual seria importante indicar se houve alguma sanção administrativa no caso brasileiro. De fato, houve a aplicação de sanção administrativa no dia 31 de janeiro de 2019 no valor de $R \$ 7.200 .000,00$ pela Secretaria Nacional do Consumidor do Ministério da Justiça no âmbito do Processo Administrativo n. 08012.000153/2016-03. Anteriormente, o IBAMA tinha aplicado uma multa no valor de $R \$ 50.000 .000,00$ também no âmbito de um procedimento administrativo. Tais valores são muito superiores ao valor da condenação judicial a título de dano moral coletivo pela 1ㅡ. Vara Empresarial da Capital do Rio de Janeiro, mas ainda assim bem inferiores em relação ao montante aplicado nos Estados Unidos, no Canadá e na Alemanha.

53 FORTES, Pedro Rubim Borges; OLIVEIRA, Pedro Farias. A quantificação do dano moral coletivo. In: ROSENVALD, Nelson; TEIXEIRA NETO, Felipe (Coords.). Dano moral coletivo. Indaiatuba: Foco, 2018, p. 335.

${ }^{54}$ FORTES, Pedro Rubim Borges; OLIVEIRA, Pedro Farias. A quantificação..., p. 335. 
No caso específico do Dieselgate brasileiro, muitos eram os critérios relevantes para a quantificação dos danos morais, não havendo qualquer motivo para se fazer uso do valor mínimo de $R \$ 1.000 .000$ (hum milhão de reais). A seguir, serão esmiuçados os critérios quantificadores consagrados na doutrina, os quais não foram devidamente considerados, bem como dois métodos de cálculo encontrados na jurisprudência brasileira e comparada, que poderiam ter sido aplicados ao caso em análise, para uma quantificação mais justa dos danos extrapatrimoniais, de modo a atender, principalmente, a função punitivo-pedagógica inerente a condenações dessa natureza.

\subsection{OS CRITÉRIOS DOUTRINÁRIOS TRADICIONAIS}

Xisto Tiago de Medeiros Neto aponta cinco critérios para a quantificação dos danos morais coletivos: (I) a natureza, a gravidade e a repercussão da lesão; (II) a situação econômica do ofensor; (III) o proveito obtido com a conduta ilícita; (IV) o grau da culpa ou do dolo, se presentes, e a verificação de reincidência; e (V) 0 grau de reprovabilidade da conduta adotada. ${ }^{55} \mathrm{Em}$ sentido semelhante, porém em mais discriminação um pouco mais profunda, Paulo Sergio Uchôa Fagundes Ferraz de Camargo defende a adoção de oito critérios: (i) conduta do ofensor; (ii) capacidade econômica do ofensor; (iii) vantagem obtida; (iv) reincidência; (v) lesão de caráter coletivo; (vi) pluralidade de réus; (vii) impossibilidade de bis in idem; e (viii) gravidade da prática. ${ }^{56}$ É evidente que todos esses critérios se mostravam presentes de forma robusta no caso do Dieselgate.

Em relação à situação ou capacidade econômica do ofensor, o Ministério Público frisou que a Volkswagen "é uma das principais empresas do ramo automobilístico, constituindo robusto conglomerado econômico que se espraia não só pelo país, mas por todo o globo". De fato, o grupo Volkswagen é o maior fabricante de automóveis do mundo, ${ }^{57}$ tendo construído um império então avaliado em $€ 422.193 .000,00$ (quatrocentos e vinte e dois bilhões, cento e noventa e três milhões de euros), segundo seu próprio relatório anual. ${ }^{58}$ Ainda no mesmo relatório, também se podia observar que o lucro do conglomerado em 2017 fora de $€$ 42.542.000.000,00 (quarenta e dois bilhões, quinhentos e quarenta e dois milhões de euros), cerca de $R \$ 175.000 .000 .000,00$ (cento e setenta e cinco bilhões de reais).

As cifras astronômicas relatadas pela fabricante explicam por que nem mesmo as significativas condenações estrangeiras conseguiram impactar seu desempenho financeiro. Nesse contexto, a condenação do judiciário brasileiro, no ínfimo valor de $R \$ 1.000 .000,00$, obviamente também não seria capaz de produzir tal efeito. Mais do que isso, o montante acima sequer seria capaz de dissuadir a empresa de cometer novo ilícito, uma vez que seus custos se revelaram extremamente baixos, quando comparados com os possíveis ganhos proporcionados pela ilicitude

\footnotetext{
55 MEDEIROS NETO, Xisto Tiago de. Dano moral coletivo. 4. ed. São Paulo: LTr, 2014, p. 210-216.

${ }^{56}$ CAMARGO, Paulo Sergio Uchôa Fagundes Ferraz de. Dano Moral Coletivo: uma possibilidade de aplicação dos danos punitivos. São Paulo: Almedina, 2016. E-book, pos. 3736/5460. 57 http://g1.globo.com/carros/noticia/2015/07/volkswagen-toma-lugar-da-toyota-como-maior-montadora-domundo.html

58 https://annualreport2017.volkswagenag.com/additional-information/five-year-overview.html
} 
lucrativa. Muito pelo contrário, a companhia e suas competidoras podem, agora, se sentir muito mais à vontade para violar normas cogentes brasileiras, uma vez que o Judiciário já demonstrou ser brando nas condenações de caráter punitivo.

Quanto ao critério de quantificação relativo à reincidência, o Ministério Público lembrou mais uma vez em sua apelação que o Dieselgate foi um escândalo global e que, em outros países, a fabricante já tinha reconhecido sua culpa, inclusive entabulando acordos para atenuar prováveis condenações. Assim, a recusa da Volkswagen em admitir seu erro perante a sociedade brasileira e em adequar a frota de automóveis vendidos revelava, segundo o órgão ministerial, causa para a majoração dos danos morais coletivos. ${ }^{59}$

Também a natureza, a gravidade e a repercussão da lesão, bem como seu grau de reprovabilidade, eram fatores críticos para o incremento da sanção. Em primeiro lugar, lembra-se que os malefícios causados pelos gases poluentes emitidos em decorrência da fraude em comento são os mais variados. Os óxidos de nitrogênio possuem efeitos malignos que são respaldados por farta evidência científica. Tais gases reagem com outras substâncias presentes em nossa atmosfera, notadamente o ozônio, formando dióxido de nitrogênio. Por sua vez, essa substância, quando inalada, provoca inflamações e reações alérgicas, com risco de asma, acidentes cardiovasculares, diabetes, bronquite e câncer. Os danos também se estendem a plantas, episódios de chuva ácida e até mesmo ao agravamento do aquecimento global. ${ }^{60}$

Em segundo lugar, a ofensa também viola diretamente o artigo 71 do Decreto $6.514 / 2008,61$ bem como o princípio da boa-fé nas relações contratuais, o dever de informação adequada ao consumidor (artigo 6ํ, III, CDC) e a vedação à publicidade abusiva e enganosa (artigo 37, CDC).

Por fim, interessante destacar trecho do acórdão proferido pela 9a Câmara Cível que, em apenas uma frase, fundamentou a manutenção do valor arbitrado para os danos morais coletivos:

Também fica o dano moral coletivo, valor de expressão mínima, diante da pujança patrimonial da Volkswagen, mas, para a dimensão Brasil, suficiente dentro do plano punitivo, repressão e prevenção à reiteração de prática de conduta lesiva aos consumidores.

Os julgadores, portanto, reconheceram que o montante quantificado se revelava de expressão mínima diante da pujança patrimonial da Volkswagen. Também não negaram o caráter punitivo, repressivo e preventivo da condenação. Apenas indicaram que, "para a dimensão Brasil", o montante era suficiente. Permanece a dúvida sobre o que exatamente seria o conceito jurídico indeterminado de "dimensão Brasil": seria a expressão de uma dependência do caminho que obriga o julgador a reconhecer a expressão mínima do valor do dano moral coletivo como suficiente apesar de saber não sê-lo? Ora, diante da reconhecida pujança patrimonial da Volkswagen, como é possível considerar um valor econômico mínimo como sendo suficiente para a prevenção de novas

59 Sobre o significado e o valor de atenuante de culpa do pedido de desculpas, SMITH, N. I was wrong: the meaning of apologies. Cambridge: Cambridge University Press, 2008.

60 EWING J. Faster, higher, farther..., p. 159-160.

61 Art. 71. Alterar ou promover a conversão de qualquer item em veículos ou motores novos ou usados que provoque alterações nos limites e exigências ambientais previstas na legislação:

Multa de $\mathrm{R} \$ 500,00$ (quinhentos reais) a $\mathrm{R} \$ 10.000,00$ (dez mil reais), por veículo, e correção da irregularidade. 
transgressões coletivas? Tais questões transcendem novamente as dimensões do caso concreto, na medida em que as condenações brasileiras ao pagamento do dano moral coletivo têm, não raro, padecido da aplicação patológica do método do arbitramento pelo valor mínimo. Assim, tratam-se de questões existenciais sobre o nosso modelo de responsabilidade civil, em que o peso da norma jurídica é esvaziado pela insustentável leveza da sanção econômica. Certo é que, independentemente do real conteúdo da referida expressão, os planos punitivo, repressivo e preventivo da responsabilidade civil tem sido insuficientemente atingidos pela condenação ao pagamento de dano moral coletivo. Ademais, não se vislumbra qualquer fator que justifique tamanha disparidade entre as condenações estrangeiras e a brasileira.

\subsection{O MÉTODO DA ESTIMATIVA FEITA A PARTIR DO MONTANTE GLOBAL DA INDENIZAÇÃO POR DANOS MATERIAIS}

A par dos critérios indicados pela doutrina especializada, também é relevante pontuar alguns métodos jurisprudenciais de recente desenvolvimento que poderiam ter sido aplicados no caso do Dieselgate. O primeiro deles é o método da estimativa feita a partir do montante global da indenização por danos materiais, que consiste na estipulação do valor indenizatório pelos danos extrapatrimoniais em razão de uma função da quantia fixada para os danos materiais. Em outras palavras, aplica-se um fator de multiplicação ao montante global da indenização material, de modo a satisfazer as demais funções da responsabilidade civil, ou seja, a punição e a dissuasão.

Nos Estados Unidos, o caso BMW v. Gore marcou um importante precedente. Após considerar que os danos punitivos arbitrados de forma excessiva e sem balizas poderiam violar a cláusula constitucional do devido processo legal substantivo, a Suprema Corte estadunidense frisou três fatores que devem ser levados em consideração no cálculo da indenização coletiva: (a) a reprovabilidade da conduta; (b) a proporção entre o valor dos danos compensatórios e dos danos punitivos; (c) comparação dos danos punitivos com a sanção civil e penal que poderia eventualmente ser imposta por um ato análogo. ${ }^{62} \mathrm{~A}$ menção à proporção entre a compensação e a punição forneceu respaldo para a tendência de aplicação de um fator multiplicativo.

No caso Exxon Shipping Co. v. Baker, ${ }^{63}$ a Corte reduziu os punitive damages então arbitrados a um valor exatamente correspondente ao montante global da indenização por danos patrimoniais. No entanto, foi além, considerando que a diminuição - de dois bilhões e meio de dólares para quinhentos milhões de dólares - se fazia necessária pelo fato de o caso versar sobre um acidente de navegação, sem dolo ou transgressão internacional do direito marítimo. Assim, foi reputada incabível a adoção do fator de multiplicação de cinco vezes o valor da indenização pelos danos materiais. Em uma interpretação em sentido contrário, portanto, a Suprema Corte reconheceu a proporcionalidade do uso do fator de multiplicação, desde que aplicado a casos diversos do analisado, em que o incremento se mostrasse adequado. Nesse contexto, o "desafio do combate à

62 BMW of North America, Inc, v. Gore, 517 U.S. 559 (1996).

63 Exxon Shipping Co v. Baker, 554 U.S. 471 (2008). 
ilicitude lucrativa consiste justamente na quantificação do dano moral coletivo sob medida, com fundamentação jurídica e otimização econômica, de maneira a que o valor seja significativo como instrumento de persuasão sem que seja exageradamente desproporcional". ${ }^{64}$

O raciocínio até aqui exposto é perfeitamente cabível para o escândalo do Dieselgate. Com efeito, foi essa a técnica utilizada pelo Ministério Público do Estado do Rio de Janeiro para chegar à cifra de $\mathrm{R} \$ 1$ 10.507.112.000,00 (dez bilhões, quinhentos e sete milhões, cento e doze mil reais) requerida em sua apelação. Partindo do pressuposto que a indenização paga a cada um dos consumidores lesados pela Volkswagen deveria ser de $\mathrm{R} \$ 154.000,00$, o Parquet multiplicou esse valor pelo número de carros comprados no Brasil que estavam equipados com o defeat device 17.057 -, chegando ao montante de $R \$ 2.626 .778 .000,00$. Tal cifra foi submetida a um fator multiplicador quádruplo, que se justificava diante do dolo da empresa, da gravidade da conduta, da recusa em reconhecer sua responsabilidade, da quebra de confiança, da falta de um pedido de desculpas e da resistência em adotar medidas concretas para solucionar o problema, redundando no mencionado valor de $\mathrm{R} \$ 10.507 .112 .000,00.65$

\subsection{O MÉTODO BIFÁSICO}

Ao contrário do método de arbitramento de valor mínimo, que é aplicado em apenas uma fase, o método bifásico pressupõe uma abordagem em duas etapas do caso concreto, para se chegar a uma justa quantificação dos danos morais. A criação da lógica supracitada pode ser atribuída ao Ministro Paulo de Tarso Sanseverino, que, no REsp 1.152.541/RS, proferiu voto magistral, posteriormente adotado por unanimidade no acórdão exarado pela Terceira Turma do STJ no recurso em questão. Frisou o ministro em sua manifestação que a "reparação dos danos extrapatrimoniais, especialmente a quantificação da indenização correspondente, constitui um dos problemas mais delicados da prática forense na atualidade, em face da dificuldade de fixação de critérios objetivos para seu arbitramento". Em seguida, o magistrado rejeitou o tarifamento legal, ressaltando que a atual prática de arbitramento equitativo pelo juiz é a melhor forma de quantificar os danos morais. Sugeriu, contudo, a adoção de critérios objetivos, no claro intuito de fugir à indesejável prática de arbitramento por valor mínimo.

Segundo a construção de Sanseverino, a primeira das etapas do método bifásico consiste em estabelecer um "valor básico ou inicial da indenização, considerando-se o interesse jurídico lesado, em conformidade com os precedentes jurisprudenciais acerca da matéria (grupo de casos)". ${ }^{66}$

${ }^{64}$ FORTES, Pedro Rubim Borges; OLIVEIRA, Pedro Farias. A quantificação..., p. 339.

65 Note-se que o valor adequado para buscar a restituição do lucro ilícito (função restitutória da responsabilidade civil) seria o total da margem de lucro com a venda dos veículos pela empresa. Todavia, a utilização do valor faturado total não se mostra equivocada, pois supre, em primeiro lugar, a falta de informações sobre a referida margem e, em segundo lugar, a punição e a prevenção necessárias à condenação, dentro de uma ótica multifuncional da responsabilidade civil, conforme já abordado acima (vide notas 30 e 31, supra).

66 BRASIL. Superior Tribunal de Justiça. Recurso Especial n.ำ1.152.541/RS. Relator: Ministro Paulo de Tarso Sanseverino, Terceira Turma, julgado em 13/09/2011, publicado em 21/09/2011. Diário de Justiça Eletrônico. Disponível

em: 
Com isso, busca-se garantir coerência e igualdade de tratamento para todos as hipóteses concretas que guardem similitude em relação à relação de direito material subjacente às suas respectivas demandas judiciais. Elimina-se, desde logo, a disparidade acentuada das condenações.

Já em um segundo momento, o método se preocupa em ajustar o valor obtido no desfecho da etapa inicial, de acordo com as nuances e circunstâncias próprias do caso que se está a analisar. Tais fatores foram resumidos por Sanseverino em cinco elementos objetivos e subjetivos de concreção, com fundamento no disseminado conceito de "concreção individualizadora" de Karl Engisch:67

a) a gravidade do fato em si e suas consequências para a vítima (dimensão do dano);

b) a intensidade do dolo ou o grau de culpa do agente (culpabilidade do agente);

c) a eventual participação culposa do ofendido (culpa concorrente da vítima);

d) a condição econômica do ofensor;

e) as condições pessoais da vítima (posição política, social e econômica).

Ao final, o método bifásico mostra-se vantajoso por congregar as virtudes de suas duas etapas: "De um lado, será alcançada uma razoável correspondência entre o valor da indenização e o

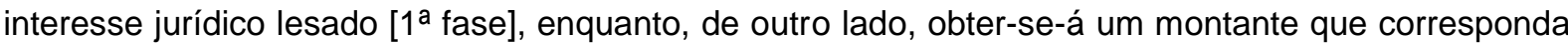
às peculiaridades do caso com um arbitramento equitativo e a devida fundamentação judicial [ $2^{2}$ fase]".

É necessário ressalvar que o REsp 1.152.541/RS tratava da quantificação de danos morais individuais, e não coletivos. Todavia, o STJ já estendeu a utilização do método bifásico para os danos extrapatrimoniais de caráter coletivo, como decidido nos REsp 1.487.046/MT e 1.517.973/PE.68 Ambos os julgados tiveram a relatoria do Ministro Luis Felipe Salomão, que redigiu a condenação, no último exemplo citado, da seguinte maneira:

\begin{abstract}
Nesse passo, suprimidas as circunstâncias específicas da lesão a direitos individuais de conteúdo extrapatrimonial, creio ser possível o emprego do referido método bifásico para a quantificação do dano moral coletivo.

Assim, em primeira fase, verifica-se que julgados desta Corte, ao reconhecerem dano moral coletivo, consideraram razoável a fixação de valores entre $R \$ 50.000,00$ (cinquenta mil reais) e $\mathrm{R} \$ 500.000,00$ (quinhentos mil reais), o que tem o condão de traduzir a relevância do interesse transindividual lesado (REsp 1.101.949/DF, Rel. Ministro Marco Buzzi, Quarta Turma, julgado em 10.05.2016, DJe 30.05.2016; REsp 1.250.582/MG, Rel. Ministro Luis Felipe Salomão, Quarta Turma, julgado em 12.04.2016, DJe 31.05.2016; REsp 1.315.822/RJ, Rel. Ministro Marco Aurélio Bellizze, Terceira Turma, julgado em 24.03.2015, DJe 16.04.2015; e REsp 1.291.213/SC, Rel. Ministro Sidnei Beneti, Terceira Turma, julgado em 30.08.2012, DJe 25.09.2012).
\end{abstract}

https://ww2.sti.jus.br/processo/revista/inteiroteor/?num_registro=200901570760\&dt_publicacao=21/09/2011 Acesso em: 05 jul. 2019. p. 16. Grifos no original.

${ }^{67}$ ENGISCH, Karl. La idea de concrecion en el derecho y en la ciencia juridica actuales. Tradução de Juan José Gil Cremades. Pamplona: Ediciones Universidad de Navarra, 1968.

68 BRASIL. Superior Tribunal de Justiça. Recurso Especial n.- 1.517.973/PE. Relator: Ministro Luis Felipe Salomão, Quarta Turma, julgado em 16/11/2017, publicado em 01/02/2018. Diário de Justiça Eletrônico. Disponível em:

https://ww2.st.jus.br/processo/revista/inteiroteor/?num_registro=201500407550\&dt_publicacao=01/02/2018 >. Acesso em: 05 jul. 2019. 
Por sua vez, em segunda fase, observadas as nuances do caso concreto (conduta dolosa causadora de dano de abrangência local; ofensor de grande capacidade econômica; incontroverso proveito econômico no importe de mais de $R \$ 90.000,00$ noventa mil reais - por programa; omissão apesar de sucessivos requerimentos do Ministério Público para a celebração de Termo de Ajustamento de Conduta; e significativa reprovabilidade social da lesão), considero razoável e adequado à função do dano moral coletivo o arbitramento da quantia de $\mathrm{R} \$ 50.000,00$ (cinquenta mil reais), consoante estabelecido na origem.

O fato de as ações coletivas abarcarem os mais diversos interesses transindividuais (vide o extenso rol do art. 1ํ da Lei n. ${ }^{\circ}$ 7.347/1985) não faz com que todas elas sejam únicas ou demasiadamente complexas. De fato, a experiência de décadas de tutela coletiva no Brasil revela que as demandas transindividuais não raro se repetem, apresentando poucas diferenças meramente circunstanciais. As falhas nas prestações de serviços por fornecedores infelizmente se reiteram, assim como as demandas na seara da improbidade administrativa e do urbanismo, por exemplo - o que pode ser, justamente, um reflexo da timidez das condenações de caráter punitivo nos tribunais pátrios. Sendo assim, o método bifásico possui plena aplicabilidade nas ações coletivas, no que se refere a ambas as suas etapas, sendo possível identificar um grupo de casos homogêneos, bem como diferenciá-los de acordo com as suas nuances de concreção individualizadora.

No caso Dieselgate, o recurso interposto pelo Ministério Público também contemplou o método bifásico. Na primeira etapa, o Parquet fez referência às ações e procedimentos instaurados em outros países para solucionar o mesmo problema de fraude no controle de emissão de gases pela Volkswagen. O bloco de precedentes judiciais, portanto, demonstrava-se especialmente robusto, com casos análogos que envolviam a mesma parte ré (grupo Volkswagen) e a mesma causa de pedir (estelionato empresarial e danos ambientais mediante a inserção de artifício fraudulento no motor de automóveis). Além disso, também seria certo que o interesse jurídico lesado permaneceria sendo o mesmo: o direito de informação ao consumidor e a proteção deste contra práticas e propagandas ilícitas, bem como o direito ao meio ambiente ecologicamente equilibrado. Bastaria, portanto, adequar o caso às circunstâncias próprias do caso concreto (gravidade do fato em si, culpabilidade do agente, culpa concorrente da vítima e condição econômica das partes etc.) para que, em última instância, se concretizassem os princípios da proporcionalidade e razoabilidade.

\section{O DESAFIO DA SUPERAÇÃO DA “INSUSTENTÁVEL LEVEZA DO SER”}

O estudo de caso do Dieselgate revela um problema sério a ser superado, a saber, um cenário em que as empresas não têm a expectativa de sofrerem sanções econômicas por conta de suas transgressões coletivas. Neste cenário, em que o ilícito coletivo compensa economicamente, as empresas não investem os recursos econômicos necessários para a prevenção de acidentes. A sociedade brasileira acaba, não raro, por sofrer com episódios de transgressões coletivas e que causam graves danos difusos, coletivos e individuais homogêneos. Ora, o peso das normas jurídicas é, na prática, esvaziado pela insustentável leveza de ser das condenações de caráter simbólico ao pagamento de valores mínimos de danos morais coletivos. O desafio da superação desse problema 
passa pela mudança de caminho interpretativo, ${ }^{69}$ pelo reconhecimento da "virada matemática" no direito ${ }^{70}$ e pelos efeitos irradiados pelas cortes sobre a realidade social. ${ }^{71}$

\subsection{DEPENDÊNCIA DO CAMINHO E A NECESSIDADE DA DEVIDA MUDANÇA}

Um dos aspectos relevantes para explicar a consolidação de uma determinada regra do jogo institucional é a dependência do caminho (path dependence), isto é, um parâmetro fixado como decorrência de uma determinada sequência de atos que pauta e define as expectativas com relação às normas que regem determinado conflito social. No caso do direito brasileiro contemporâneo, o parâmetro pode ser fixado a partir da maneira como determinado precedente judicial é formado pelo conjunto de uma série de decisões judiciais que restringem as possibilidades interpretativas como decorrência da maneira como a experiência judicial se desenvolveu. Ora, a atividade judicial se desenvolve como uma cadeia de acontecimentos correlacionados, sendo certo que a independência judicial é caracterizada pela autonomia dos juízes diante dos governantes, mas não significa que a atividade judicante não deva coerência às decisões anteriores. ${ }^{72}$

No caso do caminho interpretativo sobre o dano moral coletivo, a construção jurisprudencial ficou marcada por uma notória dissidência entre turmas do STJ. Originalmente, a $1^{\text {a }}$ Turma se dividiu em um julgamento em que o Min. Luiz Fux originalmente defendia a condenação de uma empresa ao pagamento de danos morais coletivos. Contudo, o Min. Teori Zavascki apresentou um voto divergente, em que defendia que a sociedade não sofre e, assim, não seria possível reconhecer a existência de danos morais coletivos de que seria titular a coletividade como um todo. Tal entendimento também defendido doutrinariamente por Teori Zavascki73 acabou por ser o voto condutor do julgamento original do STJ sobre o tema, estabelecendo um precedente na $1^{\text {a }}$ Turma do STJ ${ }^{74}$ que seria seguido noutros julgamentos daquele colegiado. ${ }^{75} \mathrm{Em}$ contraste com a série de julgamentos da $1^{\text {a }}$ Turma, as decisões da $2^{\mathrm{a}}$ Turma reconheceram com firmeza e veemência a existência do instituto do dano moral coletivo, reafirmando a possibilidade de que a sociedade sofra e

\footnotetext{
${ }^{69}$ Sobre o problema da "dependência do caminho" (path dependence) no direito, veja HATHAWAY, O. Path dependence in the law: the course and pattern of legal change in a common law system. lowa Law Review, lowa City, v. 86, p. 101-165, 2001, p. 101.

${ }^{70}$ Sobre a "virada matemática" (mathematical turn) no direito, veja RESTREPO-AMARILES, D. The Mathematical Turn: L'indicateur rule of law dans la politique de développement de la Banque mondiale. Gouverner par les standards et les indicateurs: de Hume au rankings, 2014, p. 193-234; RESTREPO-AMARILES, David. Transnational legal indicators: The missing link in a new era of law and development. In: Law and Policy in Latin America. Londres: Palgrave Macmillan, 2017. p. 95-111.

${ }_{71}$ GALANTER, M. The radiating effects of courts. In: BOYUM K \& MATHER L (Org.). Empirical theories about courts. Nova York: Longman, 1983; BLOOM, A. The radiating effects of torts. De Paul Law Review, Chicago, v. 62, p. 229-246, 2013, p. 229.

72 Ronald Dworkin famosamente se referiu ao encadeamento entre decisões judiciais como análoga ao encadeamento dos capítulos de uma novela - ideia que reforça a visão de que a sequência de precedentes judiciais pode resultar em uma dependência do caminho. Veja DWORKIN, R. Law's Empire. Cambridge: Harvard University Press, 1986, p. 229-238.

${ }^{73}$ ZAVASCKI, T. A. Processo coletivo: tutela de direitos coletivos e tutela coletiva de direitos. 4. ed. São Paulo:

Revista dos Tribunais, 2009, p. 40.

${ }^{74}$ REsp 598.281/MG, 01/06/2006.

${ }^{75}$ REsp 821.891/RS, de 12/05/2008; REsp 971.844/RS, 12/02/2010; REsp 1.109.905, de 03/05/2010.
} 
de que seja potencial beneficiária do pagamento de indenização pelos danos morais coletivos. ${ }^{76}$ Posteriormente, a jurisprudência do Egrégio STJ acabaria se consolidando quanto ao reconhecimento dos danos morais coletivos também pela $3^{\mathrm{a}}$ Turma, pela $4^{\mathrm{a}}$ Turma e pela Corte Especial daquele tribunal. ${ }^{77}$ Assim, a própria $1^{\text {a }}$ Turma reviu sua posição original e evoluiu no sentido de reconhecimento firme do instituto dos danos morais coletivos. ${ }^{78}$

Contudo, se o reconhecimento foi firme no âmbito normativo, aquele colegiado não fixou o montante total da indenização por dano moral coletivo em patamar superior ao valor mínimo. A rigor, se por um lado houve a preocupação em assegurar o reconhecimento do dano moral coletivo, por outro lado não houve um esforço de quantificação do dano moral coletivo com a fixação ótima da sanção econômica adequada. Uma possível explicação para a prática judiciária de arbitramento do valor mínimo seria justamente o fato de que o instituto seria mais defensável e imune às críticas, caso o valor do montante da indenização não fosse fixado em patamar alto. Por outro lado, se essa premissa for verdadeira, o preço para o reconhecimento doutrinário e jurisprudencial dos danos morais coletivos dentre nós foi um achatamento do valor do montante indenizatório como resultado da dependência do caminho na construção do conjunto de precedentes judiciais. O fato é que o STJ raramente fixou uma condenação em valor superior a um milhão de reais e, por outro lado, já se valeu do princípio da proporcionalidade para reduzir o montante do dano moral coletivo para valores inferiores a um milhão de reais.

Ora, o estudo de caso do Dieselgate evidencia com enorme clareza que o sistema brasileiro de responsabilidade civil é influenciado negativamente pelo valor mínimo e irrisório das sanções econômicas. O direito comparado possui um caráter extremamente didático, na medida em que revela que um fato idêntico deu origem a sanções econômicas bilionárias nos Estados Unidos, no Canadá e na Alemanha e, em contraste, o Poder Judiciário brasileiro aplicou uma sanção de um milhão de reais. A constatação de que a sanção brasileira é muito inferior às desses países indica a necessidade de uma mudança no caminho jurisprudencial do STJ, de maneira a que o dano moral coletivo possa cumprir sua função punitiva, precaucional e dissuasória. ${ }^{79}$

\subsection{A "VIRADA MATEMÁTICA" DO DIREITO: A NECESSIDADE DA DEVIDA QUANTIFICAÇÃO}

Um outro aspecto importante para a análise da questão-problema é a chamada "virada matemática" do direito. Conforme a precisa lição de RESTREPO-AMARILES, valores, normas e princípios jurídicos são representados atualmente por fórmulas matemáticas, indicadores jurídicos e equações numéricas. ${ }^{80}$ Tal ensinamento se torna precioso diante da existência da necessidade de se

\footnotetext{
76 REsp 1.057.274/RS, de 01/12/2009; REsp 1.150.530/SC, de 18/02/2010.

77 REsp 1517973/PE, de 16/11/2017; REsp 1487046/MT, de 28/03/2017; EREsp 1367923/RJ, de 15/02/2017.

78 AgRg no REsp 1283434/GO, de 07/04/2016.

79 POLINSKY, M. A; SHAVELL, Steven. Punitive damages..., p. 869.

80 RESTREPO-AMARILES, David. The mathematical turn: l'indicateur rule of law dans la politique de développement de la Banque mondiale. Gouverner par les standards et les indicateurs: de Hume au rankings, 2014, p. 193-234; RESTREPO-AMARILES, David. Transnational legal indicators: the missing link in a new era of law and development. In: Law and Policy in Latin America. Londres: Palgrave Macmillan, 2017. p. 95-111;
} 
calcular os danos morais coletivos sem configurar sub-dissuasão (under-deterrence) ou sobredissuasão (over-deterrence). Na hipótese de sub-dissuasão, o regime de incentivos econômicos não desencoraja a transgressão coletiva e nem os possíveis acidentes coletivos - induzindo comportamentos pouco seguros como decorrência do fenômeno da ilicitude lucrativa. ${ }^{81} \mathrm{Na}$ hipótese de sobre-dissuasão, a seu turno, o regime de incentivos econômicos estaria calibrado em patamar superior, de maneira a que os investimentos em prevenção de transgressões e acidentes coletivos poderiam ser excessivos e se converteriam em prejuízo econômico posteriormente internalizado por consumidores e acionistas. ${ }^{82}$

O presente estudo de caso do Dieselgate e seu desdobramento no direito brasileiro evidenciam que devemos levar a aplicação matemática do direito a sério. O cálculo preciso do valor a ser aplicado como parte das condenações é extremamente importante para a calibragem do peso da justiça na aplicação do regime de responsabilidade civil. ${ }^{83}$ No caso dos Estados Unidos, por exemplo, foi desenvolvida a técnica de estimativa a partir do montante do valor global dos danos materiais para que a sanção cível seja proporcional ao prejuízo social causado, que deve ser multiplicado por um fator de probabilidade de descoberta, investigação e punição pela transgressão coletiva. ${ }^{84} . \mathrm{Na}$ experiência estadunidense, o cálculo foi desenvolvido como uma estratégia dos tribunais de estabelecer parâmetros razoáveis e proporcionais para o montante total dos danos punitivos fixados pelos júris populares - com o objetivo de evitar julgamentos erráticos e que se tornassem obstáculos para o desenvolvimento econômico. ${ }^{85} \mathrm{Na}$ experiência do direito alemão, ${ }^{86}$ a técnica da desnatação

FORTES, Pedro Rubim Borges Fortes. How legal indicators influence a justice system and judicial behavior: the Brazilian National Council of Justice and 'justice in numbers'. The Journal of Legal Pluralism and Unofficial Law, Reino Unido, v. 47, n. 1, 2015, p. 39-55.

81 Eventualmente alguém poderia imaginar que as ações coletivas não sofrem com o problema de sub-dissuasão porque, em tese, ocorreria a agregação de todos os casos individuais, mas a realidade da experiência concreta é que se verificam os mesmos problemas de detecção de ilícito, identificação de lesados e aplicação do direito típicos das ações individuais e da fiscalização administrativa. Levantamento recente mostra que um número ínfimo de consumidores se habilita nas ações coletivas para receber seu quinhão da indenização. Veja: https://oglobo.globo.com/economia/defesa-do-consumidor/voce-pode-ter-direito-uma-indenizacao-nem-sabe-124044903 (checado em 26/11/2019). No caso concreto do Dieselgate no Brasil, por exemplo, a situação se repete e o número de lesados que se habilitou no processo judicial coletivo é apenas uma fração pequena do universo de consumidores lesados.

82 POLINSKY, M. A; SHAVELL, Steven. Punitive damages..., p. 869.

83 Historicamente, no caso da responsabilidade civil culposa, o juiz Learned Hand desenvolveu uma fórmula matemática para a determinação da violação de um dever de cuidado no caso concreto, cuja expressão é $P \times L>$ $B$, em que $B$ é o custo da adoção das precauções, $P$ é a probabilidade da ocorrência do evento danoso e $L$ é a gravidade do evento danoso. A aplicação da fórmula no julgamento de United States v. Carroll Tow \& Co., 159F.2d 169 (2d circuit 1947), foi um episódio pioneiro da virada matemática no campo da responsabilidade civil, consistindo no cálculo da negligência.

84 POLINSKY, M. A; SHAVELL, Steven. Punitive damages..., p. 869.

85 Veja, a respeito, SUNSTEIN, Cass R.; HASTIE, Reid; PAYNE, John W; SCHKADE, David A.; VISCUSI, W. Kip. Punitive damages: How juries decide. Chicago: University of Chicago Press, 2008.

${ }^{86}$ Costuma-se afirmar que na Alemanha não há danos punitivos, mas o Professor Volker Behr leciona que a jurisprudência dos Tribunais alemães contraria o monismo defendido em sede doutrinária de que a função da responsabilidade civil seria meramente compensatória: "as cortes alemãs frequentemente concedem indenizações que não podem seriamente ser consideradas como puramente compensatórias porque elas tendem a incluir elementos punitivos". BEHR, Volker. Punitive damages in American and German Law: tendencies towards approximation of apparently irreconcilable concepts. Chicago-Kent Law Review, Chicago, v. 78, p. 105-161, 2003, p. 126. Nesse brilhante artigo, o Professor da Universidade de Augsburg esclarece que existe uma zona cinzenta a partir da análise dos conceitos de compensação, enriquecimento sem causa e danos punitivos, tendo se "desenvolvido uma tentativa sistemática de aplicação do princípio subjacente de que a conduta ilegal não deve se pagar”. BEHR, Volker. Punitive damages..., p. 147. No caso do Dieselgate na 
pela retirada do excesso do lucro ilegítimo ("skimming off") também estabeleceu parâmetros razoáveis para a eliminação do lucro ilícito sem que se imponha prejuízos econômicos excessivos que pudessem comprometer a estabilidade econômica das empresas. ${ }^{87}$

$\mathrm{Na}$ experiência do direito brasileiro, contudo, existe um cenário de ilicitude lucrativa, em que as condenações são calculadas pelo valor mínimo e acabam gerando o enriquecimento ilícito dos transgressores coletivos. Em um regime de responsabilidade civil pautado pela sub-dissuasão (underdeterrence), as condutas ilícitas não são coibidas, diante da expectativa de que não serão impostas sanções econômicas às violadoras das normas jurídicas. Neste contexto, agentes econômicos racionais tendem a seguir os padrões de comportamento tipicamente adotados pelos demais atores relevantes de um determinado segmento de mercado. No caso brasileiro, o desdobramento do Dieselgate é um exemplo pródigo da insustentável leveza de nossas sanções econômicas, na medida em que os valores aplicados foram milhares de vezes inferiores ao valor fixado pelo poder judiciário brasileiro. ${ }^{88} \mathrm{Em}$ relação à questão-problema, a ilicitude lucrativa é influenciada pela quantificação dos danos morais coletivos na medida em que os valores fixados são extremamente baixos e, não raro, compensa economicamente violar a regra jurídica.

Alemanha, por exemplo, houve um acordo entre o Ministério Público de Braunschweig e a empresa para que fosse feito o pagamento de cerca de um bilhão de reais a título de sanção pecuniária para compensar as "vantagens pecuniárias" decorrentes da fraude empresarial. Veja: https://oglobo.globo.com/economia/volkswagen-anuncia-que-pagara-multa-de-1-bilhao-de-euros-na-alemanha22776120 (checado em 26/11/2019). A empresa teria sido obrigada a pagar um total de 2,3 bilhões de euros em multas e ainda está se defendendo em uma ação coletiva movida por uma associação de consumidores lesados que agrega interesses individuais homogêneos de cerca de 450.000 indivíduos proprietários de carros a diesel. Veja: https://www.em.com.br/app/noticia/internacional/2019/09/30/interna_internacional,1089012/comeca-naalemanha-grande-julgamento-contra-volkswagen-pelo-dieselgat.shtml (checado em 26/11/2019).

87 WÖSTHOFF, Meinrad. Collective redress from a judicial perspective. In: LEIN, Eva; FAIRGRIEVE, Duncan; CRESPO, Marta Otero; SMITH, Vincent (Org.). Collective redress in Europe - why and how? Londres: BIICL, 2015 , p. 86.

88 Um revisor anônimo questionou se o cálculo realizado considera o fato de que o volume de automóveis a diesel comercializados no exterior foi muito superior ao brasileiro. A rigor, tal aspecto foi considerado na análise, tendo sido feito uma estimativa da equivalência do peso da sanção coletiva aplicável a partir do número de automóveis fraudados nos Estados Unidos e do número de veículos Amarok considerados fraudulentos no âmbito da sentença da 1a Vara Empresarial da Capital do Estado do Rio de Janeiro: 17.057 relativos ao modelo 2011 e 2012. A sentença restringiu sua condenação aos veículos dotados do motor EA 189 e excluiu cerca de 67.000 veículos a diesel comercializados em 2013, 2014, 2015 e 2016 do âmbito da responsabilidade da empresa por falta de provas (a despeito de se tratar de uma fraude global relativa a todos os veículos a diesel comercializados no mundo todo). Assim, o montante foi calculado a partir dos valores aplicados mediante acordo no processo judicial coletivos nos Estados Unidos, reduzindo o valor justamente com base no fato de que o número de automóveis ser inferior. Logo, se nos Estados Unidos, o valor da condenação pelos danos morais coletivos foi de $R \$ 308$ bilhões para 500.000 consumidores, no Brasil o valor equivalente seria de $R \$ 10,5$ bilhões para 17.057 consumidores. Caso se considerasse o universo total de 84.000 consumidores proprietários dos veículos Amarok a diesel, o montante equivalente deveria ser de $R \$ 51.744 .000 .000,00$. Teve-se, ainda, o cuidado de se analisar o valor de mercado dos veículos Amarok para se aferir se haveria alguma disparidade entre o valor médio dos veículos estadunidenses e brasileiros que justificasse um cálculo diferente. Também nesse aspecto não existia diferença, na medida em que os veículos Amarok são automóveis com valor médio de cerca de $R \$ 154.000,00$ - equivalente ao padrão da estimativa de condenações nos Estados Unidos e na Alemanha - e que o valor da fração de dano moral coletivo por episódio individual correspondia justamente a quatro vezes tal valor, isto é, $R \$ 616.000,00$. 


\subsection{OS EFEITOS IRRADIADORES DAS CORTES: A NECESSIDADE DE INFLUENCIAR COMPORTAMENTOS}

Um aspecto essencial para a questão é a análise dos efeitos irradiadores das cortes, especialmente a capacidade das decisões judiciais de disseminar valor e crenças culturais e de influenciar comportamentos sociais. ${ }^{89}$ Além de influenciar a conduta individual e empresarial através do efeito de dissuasão decorrente do peso de suas decisões, os tribunais pautam os termos em que as partes negociam acordos extrajudiciais - na medida em que o poder de barganha das partes e o potencial de se chegar a um acordo é resultado das expectativas sobre como o Poder Judiciário viria a decidir em casos análogos. ${ }^{90} \mathrm{O}$ fluxo de influência judicial para a sociedade é modulado pelas mensagens normativas transmitidas pelas cortes e pelos processos de recepção e tradução da comunicação para a sociedade como um todo. ${ }^{91}$ Mesmo na ausência de responsabilização e de punição, as cortes podem ter efeitos irradiadores a partir de sanções simbólicas percebidas pelo grande público como sendo "estigmas" ou "ameaças". ${ }^{92}$ Os mecanismos importantes de influência são a aculturação - mensagens normativas que estimulam pessoas a mudar sua avaliação, bem como seus valores culturais e práticas - e a validação normativa - efeito de legitimar ou intensificar as atitudes existentes. ${ }^{93}$ Interessante, as mensagens normativas do direito podem ter ressonância cultural, mesmo se houver uma conexão reduzida com a perspectiva de responsabilização ou punição. ${ }^{94}$

No caso da experiência brasileira, os efeitos irradiadores das cortes têm potencial para influenciar os comportamentos individuais e empresariais. Contudo, o estudo de caso do Dieselgate evidencia que a condenação não influenciou uma mudança de comportamento por parte da empresa. Ao contrário dos Estados Unidos, no Brasil a empresa jamais pediu desculpas publicamente pela fraude global e pela lesão causada a dezenas de milhares de consumidores e à sociedade como um todo. Além disso, se nos Estados Unidos, o receio de uma condenação judicial bilionária estimulou a empresa a abrir negociação com as autoridades e a fechar um acordo para o pagamento de indenizações no valor de cerca de 15 bilhões de dólares, no Brasil a empresa recusou um convite do autor da ação civil pública para negociar um Termo de Ajustamento de Conduta e encerrar o processo coletivo. Além disso, nos Estados Unidos, a empresa se comprometeu a manter dois fundos bilionários para fins de desenvolvimento de tecnologia para carros elétricos e para a recomposição do meio ambiente lesado, ao passo que no Brasil não precisou assumir qualquer compromisso equivalente. Finalmente, nos Estados Unidos a empresa teve que recomprar centenas de milhares de carros dos consumidores lesados (buy back) e mantém esses carros fraudulentos em depósitos sem a possibilidade de revende-los, enquanto que no Brasil não adotou providências análogas para o reparo dos veículos programados com o artifício fraudulento (defeat device). Aliás, um sintoma da

\footnotetext{
${ }^{89}$ GALANTER, M. The radiating effects..., p. 118-124.

90 MNOOKING, R. H.; KORNHAUSER, L. Bargaining in the Shadow of the Law: the case of divorce. Yale Law Journal, New Haven, v. 88, p. 950-997, 1979, p. 950.

91 GALANTER, M. The radiating effects..., p. 118.

92 GALANTER, M. The radiating effects..., p. 127.

93 GALANTER, M. The radiating effects..., p. 125.

${ }_{94}^{4}$ GALANTER, M. The radiating effects..., p. 127.
} 
falta de efeitos irradiadores das cortes é que a empresa não reconhece ter cometido a fraude no Brasil, argumentando que o software instalado em onze milhões de veículos em todo o mundo - um código programado para apenas conter a emissão de gases poluentes durante os testes de laboratório - estaria desativado nos carros comercializados no Brasil.

Enfim, as sanções econômicas constituem um repertório amplo de possíveis consequências jurídicas impostas aos atos ilícitos dentro dos regimes de responsabilidade criminal, administrativa e cível. O estudo de caso do Dieselgate no Brasil revela que esse repertório complexo não tem sido efetivo instrumento para influenciar comportamentos pessoais e empresariais, ao contrário da experiência de outros países. Logo, é necessária também a adoção das medidas necessárias para que nossas cortes sejam capazes de influenciar os comportamentos individuais e empresariais, disseminando valores culturais e normativos para que sejam assegurados os direitos transindividuais e evitados novos danos difusos, coletivos e individuais homogêneos de enorme gravidade social.

\section{CONCLUSÃO}

O Dieselgate é um estudo de caso excelente para a aferição do peso e da calibragem das sanções econômicas aplicadas pelos diversos regimes de responsabilidade civil ao redor do globo, na medida em que uma conduta empresarial idêntica recebeu consequências jurídicas variadas conforme o país. ${ }^{95}$ Por um lado, cada sociedade desenvolve o seu regime normativo a partir de características históricas, sociais e econômicas próprias, não se podendo pretender a adoção de um critério estrangeiro particular por mero mimetismo ou pela ilusão de uma falsa necessidade. ${ }^{96}$ Por outro lado, é inegável a injustificada disparidade entre as sanções econômicas para um idêntico ato ilícito atribuída a uma "dimensão Brasil", que nos convida a uma reflexão sobre a leveza das condenações e o peso dos danos coletivos para a sociedade brasileira.

\footnotetext{
${ }^{95}$ No âmbito da União Europeia, por exemplo, o escândalo do Dieselgate foi citado expressamente como fundamento para a proposta de una nova diretiva sobre tutela coletiva de direitos para aplicação mais efetiva do direito do consumidor. Veja: EU Comission, A New Deal for Consumers: Commission strengthens EU Consumer Rights and Enforcement, 11/04/2018, disponível em http://europa.eu/rapid/press-release_IP-18-3041_en.htm (acesso em 10/07/19). Apesar de manter uma retórica de reprovação aos danos punitivos, o direito europeu tem utilizado o instituto para combater a ilicitude lucrativa. Veja ANTUNES, Henrique Sousa. Das Funções Reconstitutiva e Punitiva da Responsabilidade Civil: Uma Proposta de Reforma do Código Civil Português, Revista IBERC, Belo Horizonte, v. 2, n. 1, p. 1-23, jan./abr. 2019. Na Alemanha, a tradicional Convenção Alemã de Juristas (Deutscher Juristentag) criticou em sua $72^{\mathrm{a}}$ sessão em setembro de 2018 como insuficiente a nova legislação para uma ação coletiva alemã nos seguintes termos: "a ação modelo declaratória deve ser rejeitada como inadequada, porque não enfrenta as deficiências na sanção e prevenção de violações do direito, sendo insuficiente para a administração eficiente dos eventos de lesões de massa e falho em proporcionar soluções para o sistema de justiça civil". MELLER-HANNICH, Caroline. Dieselgate: European collective redress and the New German Declaratory Action, 11/12/2018, Oxford Business Law Blog, disponível em https://www.law.ox.ac.uk/business-law-blog/blog/2018/12/dieselgate-european-collective-redress-and-newgerman-model. Acesso em: 10 jul. 2019. Enfim, o presente estudo se insere dentro de uma reflexão contemporânea ampla e profunda feita por juristas de outros países sobre seus modelos de responsabilidade civil e tutela coletiva de direitos a partir das respostas concretas à fraude global.

${ }^{96}$ UNGER, Roberto Mangabeira et al. False necessity: anti-necessitarian social theory in the service of radical democracy. Cambridge: CUP Archive, 1987.
} 
O regime de incentivos para coibir os lucros ilícitos no Brasil é insustentável. A quantificação do dano moral coletivo influencia decisivamente a configuração do fenômeno da ilicitude lucrativa, na medida em que as condenações judiciais são, em regra, pelo valor mínimo. Logo, como o ilícito compensa economicamente, a sociedade sofre com a precarização dos investimentos na prevenção de acidentes coletivos e, na prática, episódios gravíssimos se repetem. A leveza das consequências jurídicas de um acidente coletivo não possui o efeito dissuasório e as empresas não adotam o comportamento necessário para internalizar as externalidades decorrentes de suas ações e omissões. Diante das sanções econômicas ínfimas e irrisórias, o Brasil se torna um "paraíso de externalidades", cabendo à sociedade civil e não às sociedades empresariais arcar com os custos sociais decorrentes dos danos difusos e coletivos.

O fenômeno da ilicitude lucrativa acaba contribuindo para um cenário de sub-dissuasão (under-deterrence), que estabelece um ciclo vicioso em que condenações leves retiram o peso da norma e incentivam as empresas a comportamentos menos cuidadosos. ${ }^{97} \mathrm{~A}$ reiteração de condenações leves advém da dependência do caminho estabelecida por uma série de precedentes judiciais, que devem ser superados a partir de uma mudança jurisprudencial marcada pela "virada matemática" do direito e pelo cálculo adequado da quantificação do dano moral coletivo. O estabelecimento de condenações adequadas pelos nossos tribunais e a irradiação dos seus efeitos deve influenciar a conduta das empresas e recalibrar o sistema de responsabilidade civil. Em termos metafóricos, a insustentável leveza do ser cede espaço a um horizonte normativo pautado pelo sustentável peso do dever ser.

\section{REFERÊNCIAS}

ANTUNES, Henrique Sousa. Das funções reconstitutiva e punitiva da responsabilidade civil: uma proposta de reforma do Código Civil Português. Revista IBERC, Belo Horizonte, v. 2, n. 1, p. 1-23, jan./abr. 2019.

BEHR, Volker. Punitive damages in American and German Law: tendencies towards approximation of apparently irreconcilable concepts. Chicago-Kent Law Review, Chicago, v. 78, p. 105-161, 2003.

BLOOM, A. The radiating effects of torts. De Paul Law Review, Chicago, v. 62, p. 229-246, 2013.

BRASIL. Superior Tribunal de Justiça. Recurso Especial n.o 1.152.541/RS. Relator: Ministro Paulo de Tarso Sanseverino, Terceira Turma, julgado em 13/09/2011, publicado em 21/09/2011. Diário de Justiça Eletrônico. Disponível em: https://ww2.stj.jus.br/processo/revista/inteiroteor/?num_registro=200901570760\&dt_publicacao=21/09 /2011. Acesso em: 05 jul. 2019.

BRASIL. Superior Tribunal de Justiça. Recurso Especial n.ำ 1.517.973/PE. Relator: Ministro Luis Felipe Salomão, Quarta Turma, julgado em 16/11/2017, publicado em 01/02/2018. Diário de Justiça Eletrônico. Disponível em: https://ww2.stj.jus.br/processo/revista/inteiroteor/?num_registro=201500407550\&dt_publicacao=01/02 /2018. Acesso em: 05 jul. 2019.

97 Sobre a relevância do cuidado, da prudência preventiva e da precaução, veja ROSENVALD, Nelson. Um possível conceito de responsabilidade civil, Revista IBERC, Belo Horizonte, Editorial, v.1, n. 1, 3-4, 2019. 
CAMARGO, Paulo Sergio Uchôa Fagundes Ferraz de. Dano moral coletivo: uma possibilidade de aplicação dos danos punitivos. São Paulo: Almedina, 2016. E-book.

COASE, Ronald $\mathrm{H}$. The problem of social cost. In: Classic papers in natural resource economics. Londres: Palgrave Macmillan, 1960, p. 87-137.

CRANSTON, Ross. Regulating business: law and consumer agencies. [s.l]: Springer, 1979.

DWORKIN, R. Law's Empire. Cambridge: Harvard University Press, 1986.

ENGISCH, Karl. La idea de concrecion en el derecho y en la ciencia juridica actuales. Tradução de Juan José Gil Cremades. Pamplona: Ediciones Universidad de Navarra, 1968.

EU Comission, A New Deal for Consumers: Commission strengthens EU Consumer Rights and Enforcement, 11/04/2018. Disponível em: http://europa.eu/rapid/press-release_IP-18-3041_en.htm. Acesso em: 10 jul. 2019.

EWING, J. Faster, higher, farther: the inside story of the Volkswagen scandal. Londres: Bantam Press, 2017.

FORTES, Pedro Rubim Borges. How legal indicators influence a justice system and judicial behavior: the Brazilian National Council of Justice and 'justice in numbers'. The Journal of Legal Pluralism and Unofficial Law, Reino Unido, v. 47, n. 1, p. 39-55, 2015.

FORTES, Pedro Rubim Borges. O fenômeno da ilicitude lucrativa. Revista Estudos Institucionais, Rio de Janeiro, v. 5, n. 1, p. 104-132, jan./abr. 2019.

FORTES, Pedro Rubim Borges. O impacto regulatório da tutela coletiva de direitos: a definição das regras e o desenvolvimento socioeconômico. In: JUNQUEIRA, Kátia (Org.). Repensando a regulação no Brasil: novas visões e propostas. Rio de Janeiro: Synergia, 2019.

FORTES, Pedro Rubim Borges; OLIVEIRA, Pedro Farias. A quantificação do dano moral coletivo. In: ROSENVALD, Nelson; TEIXEIRA NETO, Felipe (Coords.). Dano moral coletivo. Indaiatuba: Foco, 2018, p. 325-350.

FRIEDMAN, Lawrence. Impact: How Law Affects Behavior. Cambridge: Harvard University Press, 2016.

GALANTER, M. The radiating effects of courts. In: BOYUM K \& MATHER L (Org.). Empirical theories about courts. Nova York: Longman, 1983.

HARDIN, R. The street-level epistemology of trust. Politics \& Society, Londres, v. 21, n. 4, p. 505-529, 1993.

HARDIN, R. Trust and Trustworthiness. Nova York: Russell Sage Foundation, 2002.

HATHAWAY, O. Path dependence in the law: the course and pattern of legal change in a common law system. lowa Law Review, lowa City, v. 86, p. 101-165, 2001.

HOLMES, O. W. The Path of Law. Harvard Law Review, Cambridge, v. 110, p. 991-1009, 1997.

JORDÃO, Eduardo; RIBEIRO, Maurício Portugal, Como Desestruturar uma Agência Reguladora em Passos Simples, Revista Estudos Institucionais, Rio de Janeiro, v. 3, n. 1, p. 180-209, jan./jun. 2017.

JORDÃO, Eduardo; CABRAL JÚNIOR, Renato Toledo, Teoria da Deferência e a Prática Judicial: Um Estudo Empírico sobre o Controle do TJRJ à AGENERSA, Revista Estudos Institucionais, Rio de Janeiro, v. 4, n. 1, p. 537-573, jul..dez. 2018. 
KOLBA, P. Davids gegen Goliath: Der V-W Skandal und die Möglichkeit von Sammelklagen. Wien: Mandelbaum Verlag, 2017.

KRUGMAN, Paul; WELLS, Robin. Economics. 4. ed. Nova York: Worth Publishers, 2015.

KUNDERA, Milan. The Unbearable Lightness of Being. Nova York: Harper \& Row, 1984.

LEAL, Fernando; ARGUELHES, Diego Werneck, Dois Problemas de Operacionalização do Argumento de 'Capacidades Institucionais'. Revista Estudos Institucionais, Rio de Janeiro, v. 2, n. 1, p. 192-213, jan./jun. 2016.

LLEWELLYN, K. N. A Realistic Jurisprudence - The Next Step. Columbia Law Review, Nova York, v. 30, p. 431-465, 1930.

MACDOUGALD, J. A. United States of America. In: RATTALMA, M. F. (Org.). The Dieselgate: a legal perspective. Cham: Springer, 2017.

MANKIW, N. Gregory. Principles of microeconomics. 8. ed. Boston: Cengage Learning, 2016.

MARTINS-COSTA, Judith Martins; PARGENDLER, Mariana. Usos e abusos da função punitiva (punitive damages e o direito brasileiro). Revista CEJ, Brasília, v. 9, n. 28, p. 15-32, 2005.

MEDEIROS NETO, Xisto Tiago de. Dano moral coletivo. 4. ed. São Paulo: LTr, 2014.

MELLER-HANNICH, Caroline. Dieselgate: European Collective Redress and the New German Declaratory Action, 11/12/2018, Oxford Business Law Blog. Disponível em https://www.law.ox.ac.uk/business-law-blog/blog/2018/12/dieselgate-european-collective-redress-andnew-german-model. Acesso em: 10 jul. 2019.

MNOOKING, R. H.; KORNHAUSER, L. Bargaining in the Shadow of the Law: the case of divorce. Yale Law Journal, New Haven, v. 88, p. 950-997, 1979.

OLIVEIRA, Daniel Mitidieri Fernandes de, Algumas reflexões sobre o controle judicial da administração pública contemporânea, Revista Estudos Institucionais, Rio de Janeiro, v. 3, n. 1, p. 210-241, jan./jun. 2017.

POLINSKY, M. A.; SHAVELL, Steven. Punitive damages: an economic analysis. Harvard Law Review, Cambridge, v. 111, p. 869-962, 1997.

POSIO, G. Italy. In: RATTALMA, M. F. (Org.). The Dieselgate: a legal perspective. Cham: Springer, 2017.

POSNER, Richard A. Cost-benefit analysis: Definition, justification, and comment on conference papers. The Journal of Legal Studies, Chicago, v. 29, n. S2, p. 1153-1177, 2000.

POSNER, Richard A. Ronald Coase and Methodology. Journal of Economic Perspectives, Pittsburgh, v. 7, n. 4, p. 195-210, 1993.

POSOCCO, L. France. In: RATTALMA, M. F. (Org.). The Dieselgate: a legal perspective. Cham: Springer, 2017.

REALE, Miguel. Lições preliminares de direito. 27. ed. São Paulo: Saraiva, 2007.

RESTREPO-AMARILES, David. The mathematical turn: I'indicateur rule of law dans la politique de développement de la Banque mondiale. Gouverner par les standards et les indicateurs: de Hume au rankings, 2014.

RESTREPO-AMARILES, David. Transnational legal indicators: the missing link in a new era of law and development. In: Law and Policy in Latin America. Londres: Palgrave Macmillan, 2017. 
RIO DE JANEIRO. Tribunal de Justiça do Estado do Rio de Janeiro. Apelação Cível n. ${ }^{0412318-}$ 20.2015.8.19.0001. Relator: Jds. Des. Ana Célia Montemor Soares. Disponível em: http://www4.tjrj.jus.br/ejud/ConsultaProcesso.aspx?N=2018.001.39027. Acesso em: 04 jul. 2019.

ROSENVALD, Nelson. A responsabilidade civil pelo ilícito lucrativo: o disgorgement e a indenização restitutória. Salvador: JusPodivm, 2019.

ROSENVALD, Nelson. As funções da responsabilidade civil: a reparação e a pena civil. 2. ed. São Paulo: Atlas, 2014.

ROSENVALD, Nelson. Um possível conceito de responsabilidade civil. Revista IBERC, Belo Horizonte, Editorial, v. 1, n. 1, p. 1-4, nov./fev. 2019.

SCHMID, C. U. Germany. In: RATTALMA, M. F. (Org.). The Dieselgate: a legal perspective. Cham: Springer, 2017.

SCHNEIDER, M. Volkswagen: Eine Deutsche Geschichte. Berlin: Berlin Verlag, 2016.

SHARKEY, Catherine M. Punitive damages as societal damages. Yale Law Journal, New Haven, v. 113, n. 2, p. 347-453, 2003.

SMITH, N. I was wrong: the meaning of apologies. Cambridge: Cambridge University Press, 2008.

SUNSTEIN, Cass. Nudging: um guia (muito) resumido. Revista Estudos Institucionais, v. 3, n. 2, p. 1023-1034, jul./dez. 2017.

SUNSTEIN, Cass R.; HASTIE, Reid; PAYNE, John W; SCHKADE, David A.; VISCUSI, W. Kip. Punitive damages: how juries decide. Chicago: University of Chicago Press, 2008.

THALER, Richard, Misbehaving: the making of behavioural economics. Nova York: W. W. Norton \& Company, 2016.

TURNER, S. United Kingdom. In: RATTALMA, M. F. (Org.). The Dieselgate: a legal perspective. Cham: Springer, 2017.

TWINING, W. Bad Man Revisited. Cornell Law Review, Ithaca, v. 58, p. 275-303, 1972.

TWINING, W. Karl Llwewllyn and the Realist Movement. 2. ed. Cambridge: Cambridge University Press, 2012.

UNGER, Roberto Mangabeira et al. False necessity: anti-necessitarian social theory in the service of radical democracy. Cambridge: CUP Archive, 1987.

WÖSTHOFF, Meinrad. Collective redress from a judicial perspective. In: LEIN, Eva; FAIRGRIEVE, Duncan; CRESPO, Marta Otero; SMITH, Vincent (Org.). Collective redress in Europe - why and how? Londres: BIICL, 2015.

ZAVASCKI, T. A. Processo coletivo: tutela de direitos coletivos e tutela coletiva de direitos. 4. ed. São Paulo: Revista dos Tribunais, 2009.

Recebido: 10.07 .2019

Aprovado: 13.11 .2019

Como citar: FORTES, Pedro Rubim Borges; OLIVEIRA, Pedro Farias. A Insustentável Leveza do Ser? A quantificação do dano moral coletivo sob a perspectiva do fenômeno da ilicitude lucrativa e o caso Dieselgate. Revista IBERC, Minas Gerais, v. 2, n. 3, p. 1-30, set./dez. 2019. 